\title{
Non-surface Attached Bacterial Aggregates: A Ubiquitous Third Lifestyle
}

\author{
Yu-Ming Cai ${ }^{1,2 *}$ \\ ${ }^{1}$ National Biofilms Innovation Centre, Institute for Life Sciences, University of Southampton, Southampton, United Kingdom, \\ ${ }^{2}$ Biological Sciences, Institute for Life Sciences, University of Southampton, Southampton, United Kingdom
}

Bacteria are now generally believed to adopt two main lifestyles: planktonic individuals, or surface-attached biofilms. However, in recent years medical microbiologists started to stress that suspended bacterial aggregates are a major form of bacterial communities in chronic infection sites. Despite sharing many similarities with surface-attached biofilms and are thus generally defined as biofilm-like aggregates, these non-attached clumps of cells in vivo show much smaller sizes and different formation mechanisms. Furthermore, ex vivo clinical isolates were frequently reported to be less attached to abiotic surfaces when compared to standard type strains. While this third lifestyle is starting to draw heavy attention in clinical studies, it has a long history in natural and environmental sciences. For example, marine gel particles formed by bacteria

Edited by: Gordon T. Taylor, Stony Brook University, United States

Reviewed by: Yang-Chun Yong, Jiangsu University, China Tracy Mincer, Florida Atlantic University, United States

${ }^{*}$ Correspondence: Yu-Ming Cai yc2m18@soton.ac.uk

Specialty section This article was submitted to Microbiological Chemistry and Geomicrobiology, a section of the journal Frontiers in Microbiology

Received: 30 April 2020 Accepted: 13 November 2020 Published: 04 December 2020

Citation:

Cai Y-M (2020) Non-surface Attached Bacterial Aggregates:

A Ubiquitous Third Lifestyle.

Front. Microbiol. 11:557035. doi: 10.3389/fmicb.2020.557035 attachment to phytoplankton exopolymers have been well documented in oceans; large river and lake snows loaded with bacterial aggregates are frequently found in freshwater systems; multispecies bacterial "flocs" have long been used in wastewater treatment. This review focuses on non-attached aggregates found in a variety of natural and clinical settings, as well as some recent technical developments facilitating aggregate research. The aim is to summarise the characteristics of different types of bacterial aggregates, bridging the knowledge gap, provoking new perspectives for researchers from different fields, and highlighting the importance of more research input in this third lifestyle of bacteria closely relevant to our daily life.

Keywords: bacterial aggregates, marine gel particles, marine/river/lake snow, activated sludges, chronic infection, in vitro models

\section{INTRODUCTION}

The past 150 years have witnessed numerous breakthroughs in understanding the biology, biochemistry and ecology of free-swimming single celled planktonic bacteria following Louis Pasteur and Robert Koch's seminal contributions. Clusters of bacterial cells on hard surfaces were observed by Leeuvanhoek as early as 1684, but the concept remained under explored for another 250 years. Then the 1930s embraced Paul Zobell's extensive research on marine bacterial "films" on glass slides (Zobell and Allen, 1933; Zobell and Allen, 1935, Zobell and Anderson, 1936; Zobell, 1943), inspiring Bill Costerton to popularise the term "biofilm" to describe cells growing on surfaces as complex communities (Nickel et al., 1985). Ever since the concept that "the predominant lifestyle of bacteria found in natural settings are biofilms attached to 
surfaces" being brought forwards by the first generation biofilmers, research and progress has been mainly focussed on attached biofilms generated on different surfaces under specific conditions, such as the well-known mushroom structure in flow cell systems (Ma et al., 2009), or the crystal violet stained rings in microtiter plates (O'Toole, 2011). While these models are easily achievable in vitro, microbiologists from different fields started to question whether this mode is prevalent after examining samples from environment and patients. Recent studies raised the concept of a third lifestyle among medical microbiologists-non-attached bacterial clusters, which are proposed to be more prevalently found in chronic infections (Bjarnsholt et al., 2009, 2013; Secor et al., 2018). The term "aggregates" are applied to distinguish suspended clusters from surface-attached biofilms, which show some degree of similarity such as antibiotic tolerance, but also considerable differences in their phenotypes and regulatory mechanisms in vivo. As such, it is important to regard aggregates as a distinct existing format of bacteria more clinically relevant. However, suspended bacterial aggregates have been well studied in environmental science for many years. For instance, extensive studies on marine gel particles (MGP) and associated bacterial communities in sea surface waters, as well as the formation and fate of these aggregates during their sedimentation to the deep ocean were conducted by different groups (Zhou et al., 1998; Passow et al., 2001; Passow, 2002b; Engel, 2004; Cunliffe and Murrell, 2009; Cunliffe et al., 2009a,b; Ortega-Retuerta et al., 2009a; Galgani and Engel, 2013; Taylor et al., 2014; Busch et al., 2017; Engel et al., 2017; Mari et al., 2017; Zäncker et al., 2019). Large size activated sludges composed of bacteria and protozoa have been optimised and applied to the treatment of municipal wastewater (Sheng et al., 2010). Recognition of the ubiquitous nature of the aggregate lifestyle is now raising a number of fundamental questions: How are these non-attached bacterial aggregates formed? What are their functions both in nature and our bodies? Are there any fundamental similarities shared among aggregates formed in very different environments? Can we learn something from nature to help fight chronic diseases? Just as the pioneering marine work on biofilms led to the later clinical discoveries, the aggregates in marine, freshwater, wastewater and medical settings are summarised here, which may bring in inspirations on new directions of mechanistic studies, as well as more effective treatment strategies.

\section{FINDING NEMO-SEARCHING FOR THE BACTERIAL AGGREGATES IN MARINE GEL PARTICLES}

Bacteria living in fluctuating aquatic environments, such as the ocean, do not necessarily live a single cell lifestyle like that experienced in shaken laboratory cultures. In fact, microorganisms in oceans readily inhabit MGP which provide physical surfaces, refuges, and chemical and nutrient gradients. These particles form aggregates at all depths from the ocean surface down to the bathypelagial region (Figure 1; Passow, 2002b; Busch et al., 2017; Zäncker et al., 2019). Two most common types of MGP found in the ocean are polysaccharide-containing Transparent Exopolymer Particles (TEP) and the proteinaceous Coomassie Stainable Particles (CSP). TEP are gel-like sticky particles predominantly composed of acidic polysaccharides, which are produced abiotically by the coagulation of dissolved or colloidal exopolymers released by phytoplankton (Passow, 2002b; Engel et al., 2004; Busch et al., 2017). In contrast, CSP is also gel-like, but less sticky than TEP, containing proteinaceous polymers released during cell death and decomposition (Long and Azam, 1996; Thornton, 2018). The sticky nature, as well as the abundance of carbon, nitrogen, and phosphorus components render TEP and CSP ideal habitants for microbial cells (Zäncker et al., 2017), which can use them either as pure attachment sites or nutrient resources (Zäncker et al., 2019). The precursor materials, such as polysaccharides produced by phytoplankton living in the ocean mixed layer, serve as a major substratum of TEP and CSP aggregation. Bacteria loaded TEP aggregates can either float to the sea surface microlayer (SML) due to their buoyant nature or sink down to the deeper zones when the size and density are increased with more attached microorganisms or other particles, forming marine snow that transports nutrients. While TEP has been extensively studied due to its ubiquity and the importance in marine carbon cycle (Mari et al., 2017), research on CSP is still at the embryonic stage (Busch et al., 2017). Here, bacterial communities co-aggregated with these two types of marine particle are discussed.

\section{Aggregates in the Sea Surface Microlayer (SML)}

SML is considered to be roughly the upper most $1 \mathrm{~mm}$ of the ocean at the air-sea interface (Cunliffe and Murrell, 2009). Acting as the ocean's skin, it controls the exchange of gas, energy and matter between the air and the sea. It contains a variety of organic and inorganic matter providing accommodation for bacteria communities referred to as bacterioneuston (Figure 1A; Engel et al., 2017). The growing studies of bacterioneuston and the acknowledgment of the accumulation of gel particles has led to the concept that the SML can in many ways be regarded as a gelatinous biofilm (first proposed by John McN. Sieburth in 1983) (Sieburth, 1983; Wurl and Holmes, 2008; Cunliffe and Murrell, 2009; Flemming and Wuertz, 2019). This layer is enriched by TEP and CSP particles as has been observed in different ocean systems (Wurl et al., 2011; Engel and Galgani, 2016; Zäncker et al., 2017). Although the resource of dissolved polysaccharides mainly comes from the phytoplankton in the upper water column, especially after blooms, the low density and the positive buoyancy can raise TEP up to the SML. The SML may also be enriched with high-molecular organic compounds on the surfaces of bubbles, which are potentially more surface-active and tend to polymerise (Johnson and Cooke, 1980; Gershey, 1983; Flemming et al., 2016). This proposal was supported by the fact that TEP was generated by bubbles that were rich in covalently bound sulfate (Zhou et al., 1998), which is consistent with the observation that TEP in the SML contains a higher fraction of halfester sulphate bonding molecules than in the sub-surface water (Wurl and Holmes, 2008). 


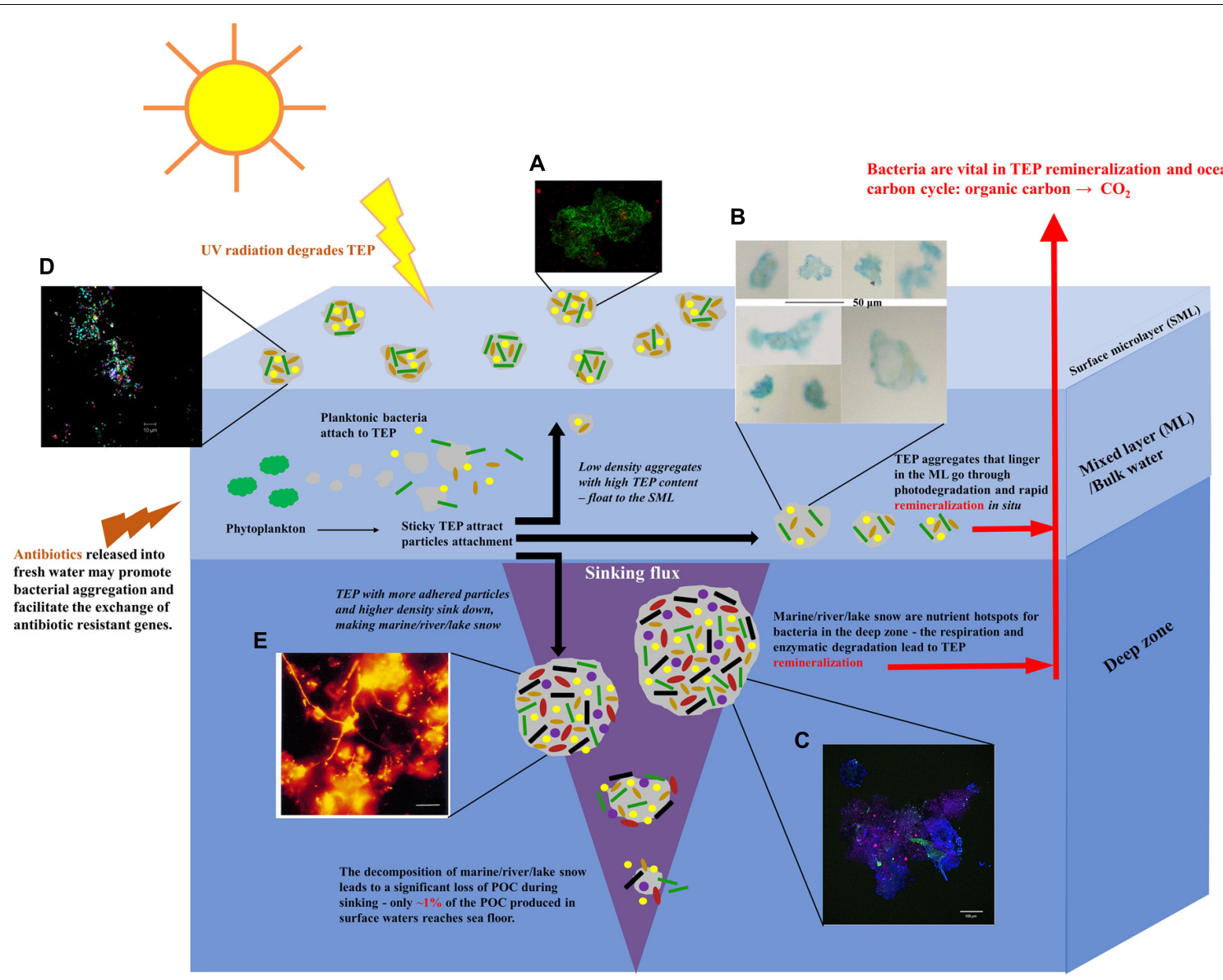

FIGURE 1 | Schematic summary of the formation of bacterial aggregates in different aquatic systems, including oceans, rivers, lakes, ponds, and estuaries. Sticky TEP produced by phytoplankton provide accommodation for different bacteria, generating aggregates. Buoyant, lightweight aggregates with high TEP content float up to the SMLs. The majority of TEP stay in the ML and attract the attachment of bacteria/solid particles. They are quickly photolysed and remineralised. More adhesive TEP accommodate more particles that increase the overall density of aggregates. These aggregates sink down to the deep zones, forming marine/river/lake snow that become nutrient hotspots for bacteria in deeper zone (Grossart and Simon, 1998a,b). The fragmentation, enzymatic degradation, bacterial respiration, and remineralisation lead to the significant loss of TEP content. Image adapted from Cunliffe and Murrell (2009); Passow and Carlson (2012), and Herndl and Reinthaler (2013). Micrographs of (A) gel particle colonised with bacteria collected from sea SML (Engel et al., 2017). (B) Light microscopy micrograph of TEP obtained from bulk water (Zäncker et al., 2019). Scale bar $=50 \mu \mathrm{m}$. (C) An aggregate collected by the Marine Snow Catcher. Blue: polysaccharides; Green: nucleic acids; Red: chlorophyll (Busch et al., 2017). Scale bar $=100 \mu \mathrm{m}$. (D) Bacterial aggregates collected from SML in a freshwater pond (Cunliffe and Murrell, 2009). Scale bar $=10 \mu \mathrm{m}$. (E) Filamentous bacteria community of "river snow" stained with fluorescent in situ hybridisation (FISH) probes (Böckelmann et al., 2000). Scale bar $=10 \mu \mathrm{m}$. Written permissions to re-use images were obtained from respective authors, journals, and/or Copyright Clearance Centre when required.

The enrichment of TEP may explain the existence of large numbers of bacteria in the SML. Apart from the gel-bacteria coagulation effect and providing nutrients, TEP may also shelter cells from the detrimental effects of factors like UV radiation, in a similar way to that of extracellular polymeric substances (EPS) which protect microbial cells in biofilms (Yin et al., 2019). Ortega-Retuerta et al. (2009a) experimentally determined how ultraviolet $B$ (UVB) radiation influenced the degradation of TEP using both natural sea water and batch culture of diatom species producing large amount of TEP. A significant TEP photolysis was observed, with loss rates from 27 to $34 \%$ per day. Interestingly, when natural sea water microorganisms were present, TEP increased greatly under UVB radiation, suggesting that UV promotes the production of TEP by microorganisms (Ortega-Retuerta et al., 2009a). As such, bacterioneuston and
TEP may mutually protect each other from the strong UV radiation occurring in the SML, and the release of TEP in the bacteria rich SML needs further attention for its role in carbon exchange.

The diversity and abundance of the bacterioneuston have been studied in recent years (Cunliffe et al., 2011; Engel et al., 2017). Different species have been discovered in SML from different locations (Franklin et al., 2005; Obernosterer et al., 2008; Cunliffe et al., 2009b; Stolle et al., 2011; Taylor et al., 2014). However, despite the widely accepted importance of TEP as the matrix holding the bacterioneuston together, the diversity of bacterial communities that specifically or preferably attach to TEP have not been widely investigated (Zäncker et al., 2019). For instance, Taylor et al. (2014) observed that an increased abundance of Flavobacteriales and Rhodobacterales belonging to Bacteroidetes 
and Alpha-proteobacteria at English Channel time-series station L4 was significantly related to the decline of TEP concentration, suggesting a role of both taxa in TEP utilisation. Stolle et al. (2011) specifically compared both the non-attached and particleattached bacterial assemblages in the Southern Baltic SML using 16S rRNA. Different strains belonging to Bacteroidetes, Cyanobacteria, Alpha-, Beta-, and Gammaproteobacteria were all found attached to particles. Obernosterer et al. (2008) also observed Bacteroidetes and Gammaproteobacteria dominating SML in the South Pacific Ocean. However, larger sample sizes collected from different locations are needed to better summarise the most prevalent orders and families associated with TEP in SML.

While many studies focussed on TEP enrichment in SML, experiments from Galgani and Engel using seawater samples from the North Sea and the diatom Thalassiosira weissflogii demonstrated an enrichment of CSP that dominated the gelatinous SML (Galgani and Engel, 2013). While bacterial abundance in SML may be strongly influenced by interactions with CSP, little is known about the diversity of bacteria attached to CSP. More knowledge of the ecology of the bacterial species specifically attaching to different particles from various locations are required for a more comprehensive picture. The results may be largely dependent on the sampling method and which parts of the SML are reached as some techniques may be biased towards specific cell types (Cunliffe and Murrell, 2009). Hence, a full comparison of all SML sampling methods would allow a better understanding of the limitations of each method and a better interpretation of the results.

\section{Bacterial Colonisation on Particles in the Mixed Layer}

The ocean mixed layer (ML) is a region of seawater situated adjacent to the air-sea interface which is subject to continuous mixing, and has relatively uniform temperature and salinity (Kantha and Anne Clayson, 2004). The pre-cursor materials for TEP, such as polysaccharides, are mainly produced by phytoplankton in the ML which is directly related to the concentration of TEP in this same layer (Ortega-Retuerta et al., 2009b; Wurl et al., 2011; Van Oostende et al., 2012). A large discrepancy was observed between the removal of dissolved inorganic carbon in the surface water and downward flux of particulate organic carbon, and the formation of carbon rich TEP generating a C-rich pool was proposed to explain this phenomenon (Sambrotto et al., 1993; Michaels et al., 1994; Schartau et al., 2007). The ML locates between the SML and the deep sea, and TEP newly produced in this area face three options for relocation-moving up to the SML, staying in the ML, and sinking down to the deeper zone. How TEP move therefore plays an important role in the oceanic carbon cycle. The density of TEP is lower than that of seawater, but due to its sticky nature the overall density of TEP aggregates can be greatly changed with the solid particles glued to them (Engel and Schartau, 1999; Azetsu-Scott and Passow, 2004). The fraction of carbon content contributed by TEP to the whole aggregate determines the degree of retention and remineralisation in surface waters vs. its downward export (Mari et al., 2017). It is now hypothesised that most TEP aggregates readily linger in surface waters, and they only sink when ballasted with high-density particles (Mari et al., 2017). In addition, the accumulation of TEP in the ML also depends on the balance between production and removal. While the main source of TEP is phytoplankton, the frequently produced EPS from bacteria can also contribute to the formation of TEP (Stoderegger and Herndl, 1999; Passow, 2002a; Sugimoto et al., 2007; Wurl et al., 2011). On the other hand, the extracellular enzymes released by bacteria attached to TEP aggregates, such as $\beta$-glucosidase and LAPase, result in the degradation and remineralisation of TEP (Arnosti et al., 2005, 2009; Bar-Zeev and Rahav, 2015; Burns et al., 2019). The abundance and species of bacteria communities colonised on the particle surfaces heavily influence the degradation of TEP aggregates in the ML. Consequently, the microscale community ecology of bacteria on particle surfaces plays an important role in the rates of carbon turnover in the ocean (Enke et al., 2018).

Despite many reports on the observation of TEP in ML from different oceans (Flemming et al., 2016), current knowledge mainly points to the abundance of bacteria associated with TEP rather than the diversity. For example, Mari and Kiørboe (1996) reported that bacterial abundance was positively related to the volume concentration of TEP sampled from the ML of Kattegat. Busch et al. (2017) analysed bacterial colonisation on both TEP and CSP in different ocean layers of the Arctic Fram Strait. The highest concentrations of bacteria attached to gel particles were observed in surface waters $(\leq 100 \mathrm{~m})$ at all stations and on both types of gel particle. TEP had the highest bacterial concentrations within the upper $30 \mathrm{~m}$ in most locations. However, neither study revealed the taxonomy inhabiting the particles. A recent study from Zäncker identified two operational taxonomic units, Marinobacter adhaerens and Glaciecola sp. Within the Alteromonadaceae family, that abundantly attached to TEP in the total bulk water sampled from Plymouth Sound (United Kingdom) (Zäncker et al., 2019; Figure 1B). Note that Alteromonadaceae does not belong to the frequently found families from SML at the other locations mentioned above. Whether the bacterial communities change drastically during ascending to SML is waiting for more detailed exploration by comparing the taxonomies presented both from SML and ML at same locations.

The fact that CSP are abundant in cultures of diatoms, cyanobacteria, and heterotrophic bacteria suggest that these organisms may also serve as a significant source of CSP in the ML (Thornton, 2018). However, little is known about whether organisms from these phyla are attached to the CSP sampled from the ocean. Heterotrophic bacteria attached to CSP may also be utilising the proteinaceous nutrients, and may account for the decreasing vertical depth profile in CSP abundance that was observed (Busch et al., 2017). Hence, the interactions between the bacteria and CSP concentrations remain to be elucidated but are likely to be complex (Thornton, 2018).

Although ML is probably where the majority of TEP and CSP originate, the diversity of bacterial communities attached to these MGPs, as well as the interaction and influence between them in a broader spectrum of locations, remain unknown. Further study 
using molecular techniques to identify the taxonomic patterns that occur within the MGPs is required in the future.

\section{Bacterial Load on Marine Snow}

The majority of TEP are of low density and retained in the euphotic zone followed by UV radiation-mediated photodegradation and in situ remineralisation (Mari et al., 2017). However, some adhesive TEP can adsorb organic matter and mineral elements, capture living organisms and promote aggregation, resulting in an increase in size and density and the production of large aggregates that sink down to the deeper zone, known as "marine snow" (Passow, 2002b; Bittar et al., 2018). Due to their high organic matter content, marine snow aggregates become nutrient hotspots for particle-attached bacteria (Flintrop et al., 2018). The microbial degradation of organic matters greatly influence the vertical transfer of carbon sources from the surface to the mesopelagic and deep ocean during the sinking of marine snow (Passow et al., 2001; Bittar et al., 2018; Flintrop et al., 2018). Furthermore, the consequence of this hydrolysis may result in a leak of material into surrounding water and generate nutrient gradients around the particles, extending the benefits to the free-floating microbes nearby and potentially increasing bacterial production (Stocker and Seymour, 2012). Consumption by zooplankton and microorganisms, bacterial respiration and enzyme-mediated remineralisation, as well as fragmentation altogether result in the fact that the portion of particulate organic carbon transported into mesopelagic zone decreases with depth, which can reduce the export flux by $\sim 70-90 \%$ (Passow and Carlson, 2012; Collins et al., 2015; Briggs et al., 2020). In the end, only $\sim 1 \%$ of the particulate organic carbon produced in surface water reaches the sea floor, and the remineralisation throughout the sinking converts the organic carbon back to $\mathrm{CO}_{2}$ (Herndl and Reinthaler, 2013). As such, the taxa and activities of bacteria associated with marine snow aggregates in the deep zone are again vital for the global carbon cycle.

Several studies have addressed the abundance of bacterial communities inhabiting marine snow (Figure 1C). Marine snow collected from different locations showed a great variance in microbial abundance (Simon et al., 1990; Thiele et al., 2015). It was reported that microbial abundance on marine snow aggregates in the northern Adriatic Sea was much higher $\left(10^{3}-\right.$ $10^{4}$ times) than the concentration of planktonic cells in the surrounding seawater (Ivancic et al., 2018). This difference in microbial abundance between marine snow aggregates and freeliving bacteria in bulk water was also observed at Cape Blanc at both 100 and $400 \mathrm{~m}$ depth (Thiele et al., 2015), indicating a potential general trend in all oceans.

Marine snow collected from surface waters were reported to be dominated by Alpha-, Gamma-Proteobacteria and organisms belonging to the Cytophaga-Flavobacterium-Bacteroides complex (DeLong et al., 1993; Gram et al., 2002). Some gram positive bacteria such as Bacillus and Clostridium were also isolated (Gram et al., 2002). However, the microbial composition in surface water marine snow may not be similar to the ones in deeper zones. Due to the difficulty in sampling, so far little is known about bacterial diversity associated with sinking marine snow. A recent study from Thiele et al. (2015) specified that the bacteria colonised on marine snow in the twilight zone belong to Roseobacter, Bacteroidetes, Alteromonas, Pseudoalteromonas, Planctomycetes, Synechococcus. There may be differences in marine snow bacterial composition between surface waters and deep ocean, but more samples are needed for wider comparisons.

As mentioned above, two of the limitations for the investigation of bacterial communities in oceans are achieving intact sampling and the deployment of in situ observation techniques. While the use of Marine Snow Catcher water sampling devices, or drifting sediment traps equipped with viscous cryogel embedding media are useful for the collection of intact marine snow (Thiele et al., 2015; Busch et al., 2017), a new method was recently developed by Flintrop et al. (2018). This uses a soft-embedding technique for the rapid quantitation of bacteria followed by sectioning with fluorescence in situ hybridisation (FISH) to study the spatial structure and components of the marine aggregates at high resolution (Flintrop et al., 2018). Future studies may focus on investigating marine snow obtained from different oceans with the combination of these techniques.

\section{SOME LIKE IT FRESH -AGGREGATED BACTERIAL COMMUNITIES IN FRESHWATER SYSTEMS}

\section{Lakes and Ponds}

One of the most extreme examples of how microorganisms can degrade freshwater quality for recreation and drinking water, as well as threatening fisheries and human health is the phenomena of cyanobacterial blooms (Huisman et al., 2018). Cyanobacterial surface blooms are often dominated by cyanobacterial aggregates (CA) formed by buoyant genera such as Aphanizomenon, Cylindrospermopsis, Dolichospermum, Microcystis, Nodularia, and Planktothrix (Huisman et al., 2018). CA are normally held together by extracellular polysaccharides released from themselves to form a phycosphere, similar to surface-attached biofilms (Zhu et al., 2019). However, cyanobacteria are not the only occupants of these large CAs. Just as TEP are mainly generated by phytoplankton but capture different species of bacteria, CAs are also extensively colonised by heterotrophic bacteria providing key nutrients (Cai et al., 2014; Woodhouse et al., 2018; Zhu et al., 2019). At least 22 bacterial divisions were found associated with CAs sampled in Lake Taihu, China, with the dominating two phyla Proteobacteria and Bacteroidetes (Cai et al., 2014). A later study from Zhu et al. (2019) revealed that Microcystis and Dolichospermum alternately dominate CAs in the same lake. Specific bacterial attachment pairs were observed for Dolichospermum-Burkholderia and Microcystis-Hyphomonas, suggesting that the co-habiting bacteria found in CAs are more correlated to the cyanobacterial content than to the specific environments (Zhu et al., 2019). Samples from a shallow eutrophic pond showed that cyanobacterial associated microbial assemblages were mainly from stable dominant taxa. A large number of bacterial-bacterial correlations were observed between these stable taxa which may be due to a high inter-dependency (Woodhouse et al., 2018). Therefore, it may be concluded that the 
dominant bacteria species attached to CAs in a specific freshwater system are more dependent on the resource of CAs rather than the environmental changes.

Bacteria can colonise organic matter in lakes, generating aggregates similar to those of marine snow, but called "lake snow" (Grossart and Simon, 1998a). Despite the fairly small sizes, "lake snow" aggregates can be densely colonised by bacteria with the abundance $100 \times$ higher than in the bulk water (Grossart and Simon, 1993). Weiss et al. (1996) found all $\alpha$-, $\beta$-, and $\gamma$-subclasses of Proteobacteria on "lake snow" aggregates in Lake Constance (Germany), with $\beta$-subclass always dominating the bacterial communities. A particular type of iron-rich lakes aggregates observed in a stratified lignite mine lake in Germany, termed as "iron snow," has been highlighted by Küsel group (Reiche et al., 2011). Iron snow associated bacteria so far isolated have been phylogenetically identified as acidophilic $\mathrm{Fe}$ (II)-oxidising bacteria related to Acidithrix (Actinobacteria) or Ferrovum ( $\beta$-Proteobacteria), as well as acidophilic heterotrophic $\mathrm{Fe}(\mathrm{III})$-reducing bacteria related to Acidiphilium, Acidisphaera, and Acidocella (a-Proteobacteria) (Lu et al., 2013; Mori et al., 2017). These results indicated that the organic or inorganic composition of the aggregate matrix can be significantly influenced by the environmental conditions and the selective dominating species, which in turn influence the taxonomic patterns of the bacteria attached to them. However, what is the general component of "lake snow" matrix, as well as how it is formed and consumed needs further research at different locations.

Bacterial aggregates are also found in ponds. Kirchman analysed the seasonal change of bacterial communities in a pond and found that particle-bound bacteria were relatively more abundant from July to October than during the cold winter months, with less than $10 \%$ of the total population attached to particles at any time (Kirchman, 1983). Alfiansah et al. (2018) reported a dominant role for Halomonas and Psychrobacter genera in the particle-attached communities in a shrimp aquaculture pond. Much bacterial aggregation was observed in the SML water collected from a freshwater pond on the University of Warwick campus (Figure 1D; Cunliffe and Murrell, 2009), suggesting that bacterial aggregation in the ponds resembles, at least to some extent, the distribution of bacteria seen in the marine system.

\section{River and Estuary}

Lotic microbial aggregates, termed "river snow," have also been documented (Böckelmann et al., 2000; Neu, 2000). The bacterial communities of "river snow" in the Elbe River (Germany) were reported to change in different seasons, showing a great diversity in spring and summer but a reduction of the total cell count was recorded in autumn and winter (Böckelmann et al., 2000). In contrast to the particle-attached taxa in the Columbia Estuary, but similar to the "lake snow" in Lake Constance, $\beta$-Proteobacteria had a dominating role, forming up to $54 \%$ of the total cell counts. Other lineages such as $\alpha$ - and $\gamma$-Proteobacteria, Planctomycetales, and Cytophaga-Flavobacteria were also detected in situ in Elbe "river snow" (Figure 1E; Böckelmann et al., 2000).
Estuaries, where freshwater meets saltwater, also witness a large number of particle-attached bacteria, sometimes making up more than fifty percent of the total community. In the Columbia Estuary (United States), most particle-attached bacterial taxa were related to members of the genus Cytophaga or the $\alpha-, \gamma-$, or $\delta$ - subclasses of Proteobacteria, while b-proteobacteria, grampositive bacteria, and Verrucomicrobium spp. mainly retained a free-living style (Crump et al., 1999). Constantly higher TEP concentrations were observed at the bottom of the Qishon estuary (Israel), heavily packed with numerous heterotropic bacterial clusters (Bar-Zeev and Rahav, 2015). Campbell and Kirchman (2013) reported that the dominating bacterial taxa in the Delaware Bay (United States) samples can change greatly along the salinity gradient in estuary, from typical fresh water communities such as Actinobacteria, Verrucomircobia, and Betaproteobacteria to typical marine communities such as Rhodobacterales, Gammaproteobacteria, and Bacteroidetes, confirming that aquatic environment plays dominant role in bacterial composition.

Apart from the need for more sampling to be carried out at other locations to further reveal the scope of bacterial interactions within lake and river snow, another serious issue has been raised recently relating to bacterial aggregation in freshwater. It is well known that antibiotic resistant genes (ARG)/isolates have been widely observed in different freshwater systems (Ash et al., 2002; Kim et al., 2015; Yang et al., 2018; Zhu et al., 2017; Nnadozie and Odume, 2019), but now sulphonamide and tetracycline resistant genes have been shown to have significantly higher abundance in particle-attached bacteria than free-living ones in the Zenne River (Belgium) (Proia et al., 2018). Guo et al. (2018) reported that the antibiotic resistant community of freeliving bacteria can be lowered during cyanobacterial blooms, but that in the particle-attached bacterial community they maintain the same abundance. This indicated that the bacteria aggregates associated with particles encouraged the stability of ARGs in the environment, which is related to the widely accepted concept that biofilms are hot spots for the horizontal transfer of ARGs, and the observations that cells encased in biofilms show much higher tolerant to antibiotics. To make the problems even more complicated, antibiotics were documented to promote the aggregation of freshwater bacterial strains in continuous laboratory cultures using artificial lake water medium (Corno et al., 2014). This phenomenon may reflect the real-life situation where the antibiotics released into freshwater facilitate the coaggregation of resistant and non-resistant isolates, which in turn results in the exchange of ARGs among strains. Once the aggregates are degraded, new resistant isolates are dispersed and spread with the potential for gene modifications to also take place. Hence, investigations into the influence of antibiotics on bacterial aggregation in different freshwater systems are urgently required.

\section{SEWAGE MILLIONAIRE-FLOCS IN WASTEWATER TREATMENT}

When our last night dinners are flushed down the toilet, they go on feeding the bacteria in sewage water. As in other water 
systems, bacteria can form multi-cellular aggregates (also known as flocs), which have been extensively studied in the activated sludges (AS) wastewater treatment plants (Jorand et al., 1995; Zita and Hermansson, 1997; Da Motta et al., 2001; Wilén et al., 2003; Nielsen et al., 2004; Larsen et al., 2008; Foladori et al., 2010). The AS process is the most prevalently applied biological wastewater treatment method, where suspended bacterial aggregates are used for removing pollutants based on their capacity to break down organic carbon substances and consume nutrients such as nitrogen and phosphorus (Gernaey and Sin, 2008).

Sludge flocs are mainly composed of microorganisms stuck together with EPS matrix, organic, and/or inorganic colloidal particles (Figure 2A; Urbain et al., 1993; Sanin and Vesilind, 1996; Bitton, 2010). Considerable attention has been paid to (1) the structure and the physico-chemical properties of flocs (Andreadakis, 1993; Snidaro et al., 1997; Wilen and Balmer, 1999; Sponza, 2002; Jin et al., 2003; Nielsen et al., 2004; Kara et al., 2008); (2) isolation and characterisation of floc forming bacteria (Nielsen et al., 2004), both important in sludge management such as flocculation, settling, dewaterability and effluent quality (Nielsen et al., 2004). Bacteria constitute $5-20 \%$ of organics in flocs, of which filamentous bacteria plays a significant role (Raszka et al., 2006; Nielsen et al., 2010). Both auto-aggregation (genetically identical cells forming flocs themselves) (Trunk et al., 2018) and co-aggregation (adherence of genetically different cells) (Malik et al., 2003) happen in flocs. The phylum Proteobacteria was documented to be dominant, with $\beta$-Proteobacteria being the most abundant class for their important roles in both producing flocs EPS (such as Zoogloea; Rossello-Mora et al., 1995; Shao et al., 2009) and in organic matter degradation (Nascimento et al., 2018). $\alpha-, \gamma-, \delta$-Proteobacteria, Actinobacteria, Bacteroidetes, Firmicutes, Chloroflexi were also found but less abundant (Nielsen et al., 2004, 2010; Larsen et al., 2008; He et al., 2016). More specifically, some core genera including Zoogloea, Dechloromonas, Prosthecobacter, Caldilinea, Tricoccus, Gp4, and Gp6 in Acidobacteria and Subdivision3 genera incertae sedis of Verrucomicrobia have been identified from all 14 activated sludge in different locations (mainland China, Hong Kong, Singapore, Canada, and United States) (Zhang et al., 2012), indicating their importance in maintaining the normal function of wastewater treatment plants.

Knowing the composition and function of bacteria communities facilitates the development of more efficient wastewater treatment methods. While AS has served as a standard technology for the biological treatment of sewage, it does have some drawbacks. For instance, the poor settling ability of active-sludge can result in the excessive loss of sludge in the effluent, thus significantly lowering the effluent quality. Furthermore, uncontrolled sludge ages can gradually lead to the loss of treatment efficiency (Nancharaiah and Kiran Kumar Reddy, 2018). A relatively advanced strategy, aerobic granular sludge (AGS), has been applied for the efficient removal of organic carbon, ammonium and nitrogen etc. (Figure 2B; Szabó et al., 2017). AGS is generated by inoculating AS to the column reactors operated in sequencing batch reactor mode with bubble aeration and short settling times. The seeded AS are first induced to form large aggregates in the reactors. Then, by repeatedly operating sequencing batch reactor with short settling time, the sludges with poor settling ability are washed out, while aggregates with rapid settling time are selected and kept for further growth. Eventually, this selection and separation resulted in large-size granular sludges with high density allowing for rapid sediment, and high EPS content improving the stability and providing cells inside with higher tolerance to the toxic pollutants (Nancharaiah and Kiran Kumar Reddy, 2018).

Some core genera have been identified in different AGS, including but not limited to Tetrasphaera, Sphingopyxis, Dechloromonas, Flavobacterium, Ohtaekwangia (Świątczak and Cydzik-Kwiatkowska, 2018), Meganema, Thauera, Paracoccus, Zoogloea (Szabó et al., 2017), Denitratisoma, Novosphingobium, Planctomyces, Ferruginibacter, Hyphomicrobium, Steroidobacter (Yuan et al., 2019). Furthermore, Ali et al. reported that the bacterial compositions among different-sized aggregates are significantly different, and this dissimilarity increases with the increase in aggregate sizes, indicating an important role of species sorting in AGS systems (Ali et al., 2019). One exciting aspect of the application of AGS is the removal of pharmaceutical and personal care products in wastewater (Xia et al., 2014; Zhao et al., 2014; Wang et al., 2016). For instance, Chryseobacterium, Actinotignum, Lactococcus, Shinella, and Clavibacter have been facilitating the removal of tetracycline (Wang et al., 2018). The removal of prednisolone, naproxen, sulphamethoxazole and ibuprofen was enabled by antibiotic-resistant genes carrier such as Firmicutes sp., Aeromonas sp. and Nitrospira sp. (Xia et al., 2014). As such, future optimisation of AGS technology relies on the better understanding of the physiology, function, and interaction of the species for more efficient separation, maintenance, and treatments.

Although AGS has been widely applied in wastewater treatment to replace the traditional AS, it is not an energy cost-effective process (Foladori et al., 2018). Microalgal-bacterial aggregates have been extensively investigated and regarded as a greener technology during the last two decades. The photosynthetically produced oxygen by microalgae support the growth of bacteria, which in return produce $\mathrm{CO}_{2}$ for microalgal photosynthesis. Together, the whole consortium substantially remove the organic matter and nutrients in wastewater, with excellent settling characteristics allowing for biomass harvesting by gravity sedimentation (Quijano et al., 2017). While the genera such as Chlorella and Scenedesmus have been reported to be a suitable algal species (Gutzeit et al., 2005; Lee et al., 2013; Mezhoud et al., 2014; Vandamme et al., 2014; Shen et al., 2015; Kinnunen and Rintala, 2016; Arcila and Buitrón, 2017), so far, most bacteria identified in wastewater treatment using microalgal-bacterial systems belong to the phyla Bacteroidetes and Proteobacteria, such as Betaproteobacteria, Bacteroidia, Flavobacteria,Gammaproteobacteria (Su et al., 2011), Sphingobacteria, Terrimonas, and Hyphomon-as (Lee et al., 2013). More detailed knowledge on the interaction between different algal-bacteria species would facilitate better design. 


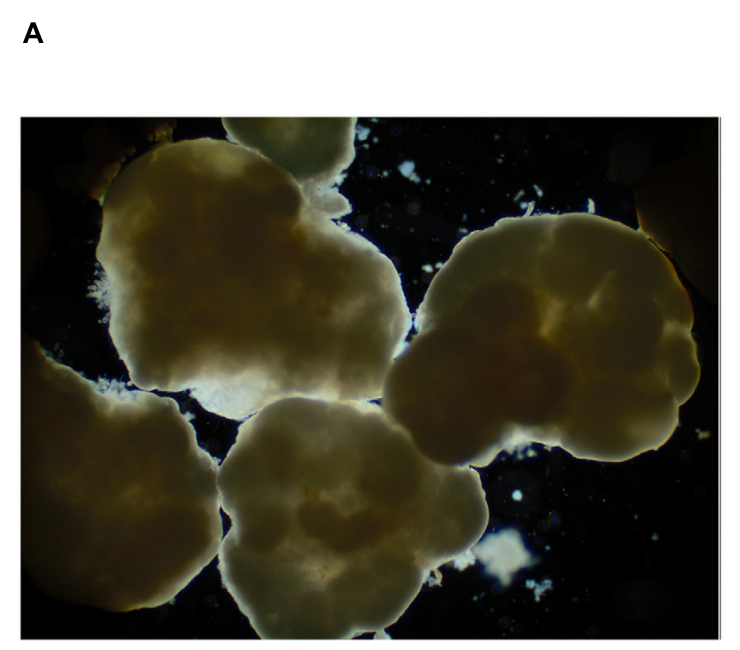

B

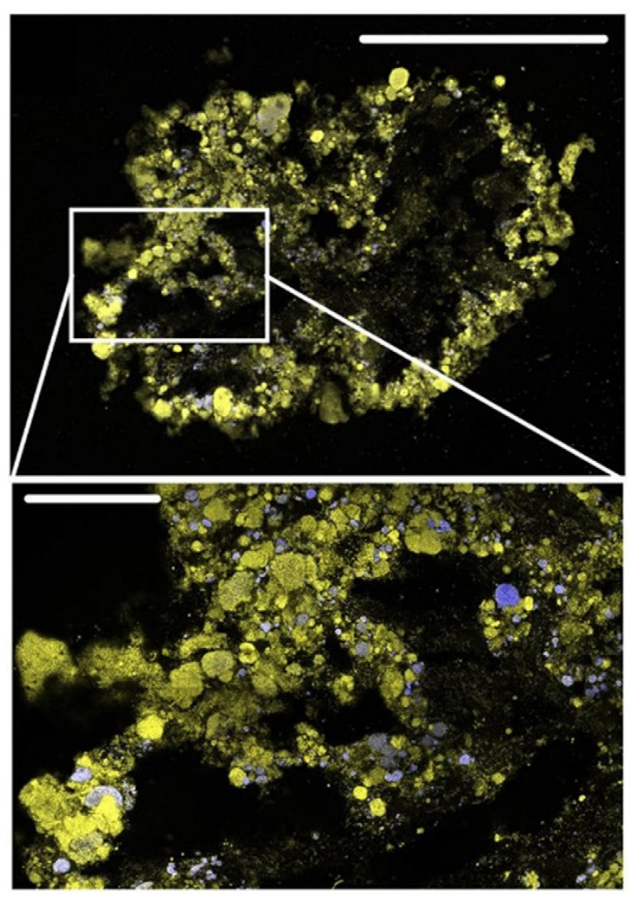

FIGURE 2 | (A) Light microscopy micrograph of aerobic granular sludge (Wilén et al., 2018). (B) FISH-CLSM images from cryosections of aerobic granular sludge (upper scale bar: $500 \mu \mathrm{m}$ ) and detailed sections (lower scale bar: $100 \mu \mathrm{m}$ ). Yellow: total cells; blue: ammonia oxidising bacteria (Szabó et al., 2017). Written permissions to re-use images were obtained from journals.

\section{TINY SIZE, BIG TROUBLE-THE IN VIVO BACTERIAL AGGREGATES}

\section{Cystic Fibrosis (CF) Airway Infection}

As the major contributor to morbidity and mortality in cystic fibrosis patients with chronic airway infection, $P$. aeruginosa has been extensively studied for its physiology in vivo. While it is well-established that $P$. aeruginosa forms substantial biofilms in vitro, whether or not they adhere to epithelial cells in CF patients has been controversial. Some earlier studies using cultured epithelial cells tended to support the adherence theory. Imundo et al. (1995) reported that tetrasaccharide of $\alpha \mathrm{GM}$ is a receptor for $P$. aeruginosa and its increased abundance in the apical membrane of CF epithelia most likely contributes to P. aeruginosa colonisation in the CF lung. Hahn (1997) further reported that it was the type IV pili of $P$. aeruginosa that was responsible for binding to $\alpha \mathrm{GM}$. Interestingly, $P$. aeruginosa was shown to not avidly bind to normal, uninjured epithelial cell surfaces, but the binding of $P$. aeruginosa to inflamed or injured epithelial cells (CF or mechanically ventilated patients) is significantly higher than to normal cells (De Bentzmann et al., 1996). However, in recent years, another theory emerged from CF ex vivo studies that has become more and more popular, supporting the fact that bacteria do not necessarily attach to surfaces for the establishment of biofilm-like aggregates that contribute to chronic infections (Campodónico et al., 2008; Alhede et al., 2011; Hall-Stoodley et al., 2012). For instance, $P$. aeruginosa can enter airway epithelial cells and internalised bacteria form clusters within airway cells, favouring their persistence that results in the difficulties in the treatment of airway infection (Garcia-Medina et al., 2005). A number of studies claimed that $P$. aeruginosa was never seen localised to the epithelial cell surface in CF airways when sputum and explanted/thin sections of airways from CF patients were examined. Instead, bacterial aggregates were found bound to mucus and surrounded by polymorphonuclear neutrophils (Figure 3A; Hassett et al., 2002; Worlitzsch et al., 2002; Bjarnsholt et al., 2009). Using artificial sputum medium, Sriramulu et al. (2005) discovered that $P$. aeruginosa form tight microcolonies, or aggregates attached to sputum components, which can be enhanced by the amino acid content via quorum sensing pathways (Sriramulu, 2010; Williams and Davies, 2012). By using mucus gels containing ex vivo sputum from patients, Staudinger et al. (2014) revealed it is neutrophil elastase in CF sputum that promotes the formation of bacterial aggregates. This was further evidenced by Caceres et al. (2014) showing that the incorporation of human neutrophil-derived products enhanced the formation of non-attached $P$. aeruginosa aggregates. The self-aggregating, non-attached $P$. aeruginosa grown in artificial CF sputum resemble those observed in the CF lung sputa both transcriptionally and phenotypically, suggesting the aggregates embedded in mucus are likely to be the prevalent growth mode at chronic infection sites (Fung et al., 2010). It is worth noting that although non-attached $P$. aeruginosa aggregates were proved to resemble surface attached biofilms in growth rate, internal structures of the matrix, tolerance to antibiotics and 


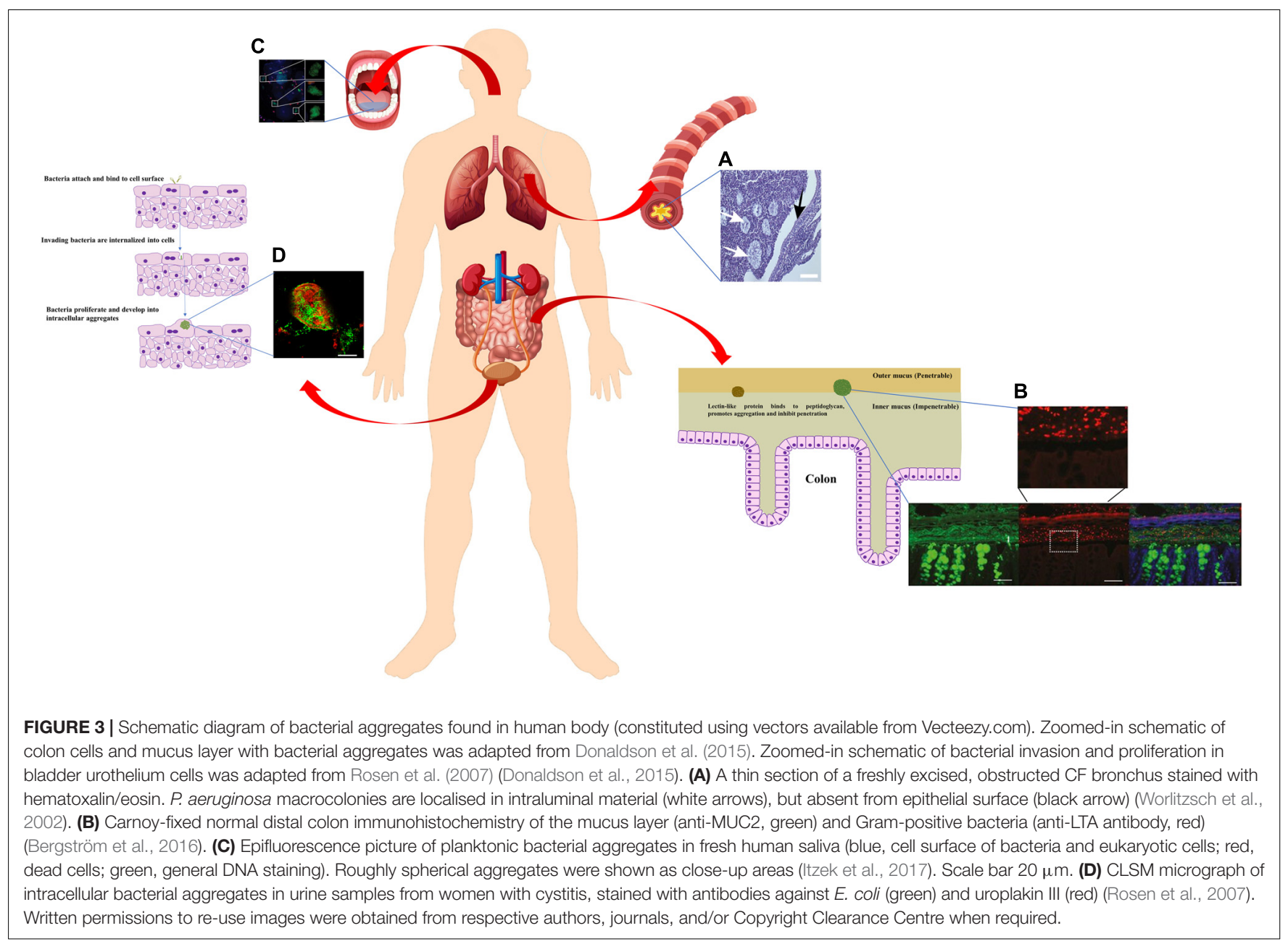

resistance to phagocytes (Alhede et al., 2011; Caceres et al., 2014), mutants that inhibit biofilm formation on surfaces still allow for aggregation in mucus under the force of abundant polymer (Staudinger et al., 2014; Secor et al., 2018). Furthermore, isolates taken from chronic CF infections are often defective in biofilm formation in standard plate assays, suggesting that the strains capable of forming aggregates in situ may not attach well to surfaces (Lee et al., 2005; Deligianni et al., 2010). The production mechanisms of non-attached aggregates embedded in polymers may be very different from surface-attached biofilms, depending on the passive "depletion aggregation" driven by entropic forces generated by polymers rather than the bacterial activities (Secor et al., 2018). Yet, such observations opened the door for fundamental research on the formation and dispersal of suspended bacterial aggregates in polymer rich environments resembling the chronic infection sites in vivo, which are more clinically relevant than microtiter plates or 2D epithelial cells for the development of better treatment strategies.

\section{Chronic Wound Infection}

Growing evidence shows that bacterial aggregates found in chronic wounds tend to be entrapped in wound beds or compromised soft tissues with extensive host polymers and debris (James et al., 2008; Pabst et al., 2016). Relatedly, different bacterial strains such as Pseudomonas aeruginosa, Staphylococcus epidermidis and Probionibacterium acnes, were found to form aggregates in soft tissue dermal fillers, exhibiting tolerance to antibiotics once established (Alhede et al., 2014). This implies that the highly hydrated in vivo environment filled with extracellular matrix such as collagen and elastin may be favoured by bacterial aggregation. When looking into biopsied leg ulcer samples from different patients, $S$. aureus are more frequently present on or near the wound surfaces, whereas $P$. aeruginosa are largely deep buried inside the wound beds surrounded by polymorphonuclear neutrophils (Kirketerp-Møller et al., 2008; Fazli et al., 2009). Moreover, $P$. aeruginosa aggregates were found to be more prevalent in diabetic wounds compared to non-diabetic wounds. They were exclusively found within the wound bed and at the wound margin, leading increased tolerance to antibiotics and impaired healing (Watters et al., 2013). Morgan et al. (2019) showed that human wound infection isolates do not form substantial biofilms in vitro. The authors further demonstrated that genetically modified $P$. aeruginosa strains defective in biofilm formation can still form aggregates in the wounds using a murine model (Morgan et al., 2019). This may indicate that bacterial aggregates imbedded in secretions, not solid surface-attached 
biofilm, may be a default growth mode driven by thick polymerrich surrounding as a consequence of host conditions. Specific mechanisms required for the formation of aggregation may be needed in vivo, which do not overlap with biofilm formation functions required in vitro (Morgan et al., 2019).

\section{Other Body Fluids}

Mucus is also found in intestines. Salmonella typhimurium was shown to aggregate and bind to colonic mucus, which is mediated by a $66-\mathrm{Kd}$ heat shock protein produced by the bacteria themselves (Ensgraber and Loos, 1992). At the same time, the host can produce abundant lectin-like protein ZG16 (zymogen granulae protein 16) in distal colonic mucus, which binds to the bacterial cell wall peptidoglycan and induces the aggregation of Gram-positive bacteria (Figure 3B; Bergström et al., 2016). As such, both bacteria and host develop mechanisms to trigger bacterial aggregation for keeping bacteria a safe distance from the colon epithelium and preventing inflammation (Bergström et al., 2016).

Interestingly, while the first description of the biofilm concept came from Leeuwenhoek examining his own scraped-off dental plaque (Høiby, 2017), saliva has been reported to facilitate the aggregation of bacteria from a number of different genera, including species such as Actinomyces israelii, Actinomyces naeslundii, Actinomyces viscosus, Bacteroides intermedius, Bacteroides gingivalis, Streptococcus cricetus, Streptococcus mutans, Streptococcus rattus, Streptococcus sanguis, Streptococcus sobrinus, Streptococcus intermedius, Streptococcus gordoni (Rosan et al., 1982; Golub et al., 1985; Koop et al., 1989; Yamaguchi, 2004; Kitada and Oho, 2012; Itzek et al., 2017). It was suggested that the interactions between salivary IgA and bacterial surface components cause bacterial aggregation, which also depends on various factors (Koop et al., 1989; Yamaguchi, 2004). As a result, saliva blocks the adherence of bacteria onto surfaces and promotes the clearance from the oral cavity. More recent studies further revealed that bacterial cells are aggregated into an ideal size by saliva for the recognition by polymorphonuclear neutrophil granulocytes, which then de-aggregate them through serine proteases for more efficient phagocytosis and killing (Figure 3C; Itzek et al., 2017). Using this elaborate pathway of modulating bacterial aggregation, saliva plays a significant role in first line defence preventing infections and damage in the bloodstream and tissues.

Uropathogenic bacterial aggregates, also known as intracellular bacterial communities, were found in planktonic form in urine from both healthy volunteers and urinary tract infection patients (Reid et al., 1990; Rosen et al., 2007; Robino et al., 2014; Conover et al., 2016). It was suggested that E. coli invades the superficial bladder cells, which are then exfoliated and removed with the flow of urine as a response to the invasion (Mulvey et al., 2001). However, bacteria find their way to multiply intracellularly and eventually establish biofilm-like aggregates (Figure 3D; Rosen et al., 2007; Robino et al., 2014; Conover et al., 2016). Also similar to biofilms growth stages, these aggregates progress through four stages, with distinct growth rates, bacterial lengths, colony organisations, motility, and dispersal (Justice et al., 2004). With evolutionary development through different stages, some physiologically adapted, filamentous intracellular bacteria could emerge from the aggregates (Mulvey et al., 2001; Justice et al., 2004). As such, these aggregates generate a dormant reservoir of pathogens inside the bladder cells, allowing for the escape from host clearance and are tolerant to antibiotics (Anderson et al., 2004). Once dispersed, the re-emerging cells may cause the recurrence of urinary tract infection, and can also be associated with chronic cystitis (Anderson et al., 2004; Schwartz et al., 2011; Robino et al., 2014). Once again it is aggregated bacteria rather than biofilms attached to solid surfaces that are causing these intractable medical problems.

\section{MODERN TIMES-NOVEL TECHNOLOGIES IN AGGREGATE RESEARCH}

\section{In vitro Models}

Each model has distinct limitations reflecting the true situation under natural or clinical settings, including many in vivo models. In vitro studies are still largely applied for their easier approach and modulation. Some modifications on traditional biofilm research protocols have proved to stimulate nonattached bacterial aggregation, which mimic the structure and characteristics of in vivo biofilm infection better than the specific surface attachment using defined conditions. Even just altering liquid medium can yield some surprising results. For example, Schleheck et al. (2009) found P. aeruginosa aggregates in shaking planktonic batch cultures using just mineral salts medium containing a limited carbon-resource. Equine or porcine synovial fluid was shown to be a successful model for growing suspended $S$. aureus aggregates to mimic human joint infections (Figures 4A-C; Gilbertie et al., 2019). Bolton broth containing 50\% plasma and 5\% freeze-thaw laked horse red blood cells (defibrinated) was used to study polymicrobial biofilms/aggregates in wound infection (Dalton et al., 2011). Synthetic sputum medium was shown to promote the formation of $P$. aeruginosa aggregates with sizes comparable to those observed in CF lungs (Darch et al., 2017). Agarose gel seeded with $S$. aureus and alginate beads inoculated with $P$. aeruginosa were developed to mimic the aggregates formed in the lung mucus or in dermal wounds matrices (Figure 4D; Pabst et al., 2016; Sønderholm et al., 2017). Apart from the relatively rough immobilisation methods to achieve bacterial aggregates as mentioned above, a much more refined method was developed using 3-D printed bacterial microtraps to control the spatial distances between bacterial aggregates (Figure 4E; Connell et al., 2014). The application of this elegant technique with proper biomarkers allows for both the control of cell number in the aggregates and the real-time monitoring of quorum sensing communication between communities, which significantly enhances the accuracy of aggregate-related studies (Connell et al., 2014). Artificial wound models have also been developed, containing a dermis-like scaffold composed of hyaluronic acid and collagen immersed into wound-like medium consisting of Bolton broth supplemented with 50\% heparinised 
A

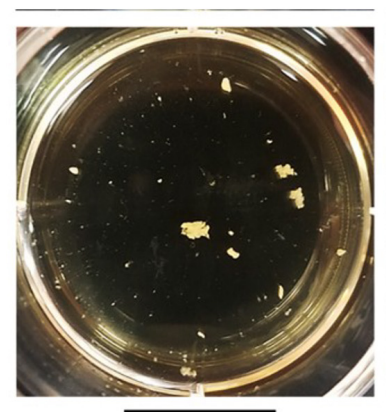

$2 \mathrm{~cm}$

D

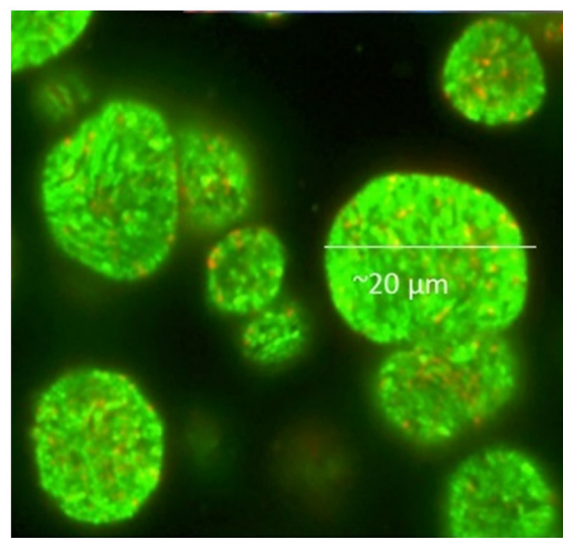

B

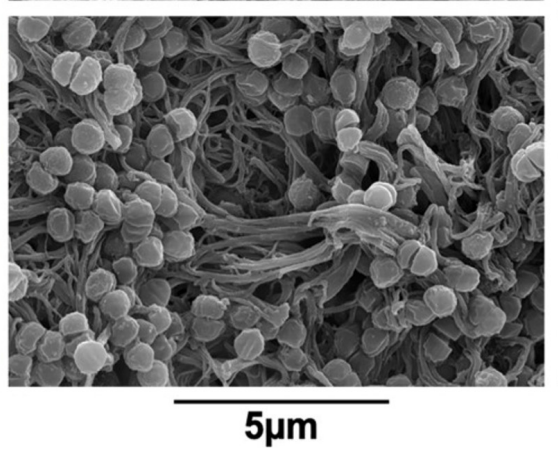

C

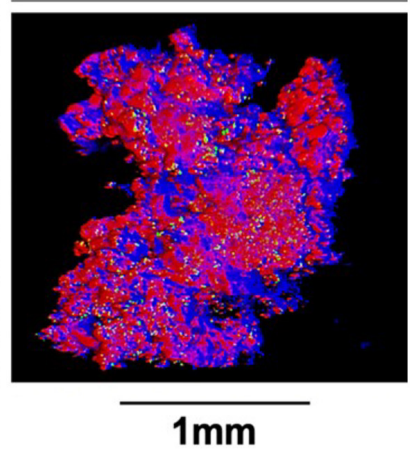

E

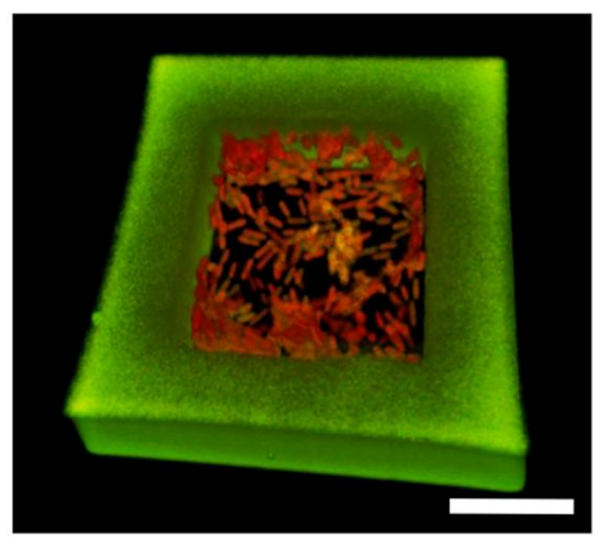

FIGURE 4 |S. aureus aggregates cultured in human synovial fluid $\left(37^{\circ} \mathrm{C}\right.$ incubation, microaerophilic chamber, $\left.120 \mathrm{rpm}\right)$ and photographed (A) in the 24 -well plates, (B) by SEM, and (C) by CLSM (Gilbertie et al., 2019). (D) CLSM micrograph of GFP-tagged P. aeruginosa PAO1 aggregates (green) grown in alginate beads

(Sønderholm et al., 2017). (E) P. aeruginosa cells contained in a 3D-printed microtrap. Scale bar $=10 \mu \mathrm{m}$. Green, the walls of microtrap; Red, the bacteria (Connell et al., 2014). Written permissions to re-use images were obtained from respective authors, journals, and/or Copyright Clearance Centre when required.

bovine plasma and 5\% freeze-thaw laked horse blood (Grassi et al., 2019). These recent in vitro models have been proved to be more clinically relevant, hence are ideal for bacterial aggregation studies.

\section{Quantitative Software and Methods}

Both descriptive and quantitative methods have been documented to describe bacterial aggregates under different settings. Microscopic or macroscopic images can be directly shown for the visual comparisons (Baugh et al., 2014; Foulston et al., 2014; Wessel et al., 2014; Jagmann et al., 2015; Zeng et al., 2015; Guo et al., 2016). Optical density (OD) values have been used for indirect measurements. For example, Guo et al. (2016) used low speed centrifugation to separate cell aggregates and planktonic cells. Cell aggregates were then collected for vortexing and CFU counting so that the cell number in aggregates was enumerated (Guo et al., 2016). Baugh et al. (2014) grew bacterial aggregates in a static system and compared the $\mathrm{OD}$ value of the suspension below the aggregating surfaces. With the same initial inoculum and growth rate, the lower the OD value of suspension (planktonic cells), the higher the aggregation levels (Baugh et al., 2014). Naturally, OD values do not directly reflect the characters of the cell aggregates themselves. Several quantification methods have been developed to calculate $2 \mathrm{D}$ micrographs. For example, software such as Image $J^{\mathrm{TM}}$ can be applied to change the aggregative structures in each image to a binary code and then the pixel number can be measured to represent the structure size (Jung et al., 2015). Stoodley et al. (2001) used image subtraction to change the grey scale of background so that the areas and diameters of cell aggregates can be measured, from which the means and standard deviations of the aggregate sizes can be calculated. With more advanced equipment, Schleheck et al. (2009) used laser diffraction analysis to determine the exact diameters of cell aggregates and different size ranges were grouped into different catagories. Similarly, a coulter counter measuring electric current change was applied to reflect the size of the particles (Zhang et al., 2013) and a cell counter can be used to count individual cells within cell aggregates (Dastghey et al., 2015). While data acquired from these devices are mostly numerical data, CLSM is a popular approach for 3-D microscopic outputs. Accordingly, different softwares have emerged to analyse 3-D bacterial structures. COMSTAT was designed for biofilm research in 2000 (Heydorn et al., 2000). Although it does calculate the volumes of microcolonies/aggregates, the microcolonies are defined as connected to the substratum (Heydorn et al., 2000) 
and hence, for non-attached aggregates in liquid cultures, this classic software may not be ideal. Another software, daime $e^{\mathrm{TM}}$ (digital image analysis in microbial ecology), was designed several years later mainly tackling 2-D and 3-D micrographs acquired from environmental and medical samples using FISH probes. 2-D and 3-D objects in images (stacks) can be automatically identified by the software package daime, which are then used to quantify microbial populations and even evaluate new FISH probes. The quantification of spatial localisation patterns of microorganisms in complex structures like biofilms is also available (Daims et al., 2006). Over the years, Image $\mathrm{J}^{\mathrm{TM}}$ has become more and more powerful with additionally coded plugins. The 3D Objects Counter and 3D Manager function from the 3-D ImageJ Suite plugin (Ollion et al., 2013) are suitable for identifying bacterial aggregates in CLSM micrographs. Similarly, another powerful software named Imaris can be used to automatically identify and quantify different parameters of 3-D aggregates, such as surface areas, diameters, and volumes. It also offers functions such as particle tracking and segmentation, which are very useful if the researcher is only interested in a particular aggregate. While Imaris is less accessible due to its expensive package and maintenance price, an open source software, BiofilmQ, also allows for processing micrographs acquired from different fluorescent microscopies (Hartmann et al., 2019). Different parameters, such as size, volume, location, distance, fluorescent intensity, and even correlation of co-localisation, can be measured in any spatially structured microbial community including microscopic, mesoscopic, macroscopic colonies, biofilms, and non-attached aggregates (Hartmann et al., 2019). Recently, a novel index, Aggregation Coefficient, was developed to more directly quantify the bacterial aggregation levels using CLSM micrographs, MATLAB and ImageJ macro (Cai et al., 2019). Each CLSM stack of images can generate a single numerical index, which makes comparison between large scale samples easier. As many breakthroughs in biological science rely on novel inventions and conquering technical bottlenecks, improvements on both microscopes imaging and the accompanying computational programs will significantly enhance our perspectives on microbial worlds.

\section{CONCLUSION AND FINAL THOUGHTS}

Bacterial aggregates are ubiquitous, but they have been considered as an alternative format of surface-attached biofilms and thus underestimated for years. In this review, the existence of non-surface attached bacterial aggregates discovered from ocean, fresh water, wastewater treatment systems, as well as chronic infection sites were collectively presented, providing new perspectives and questions based on some fundamental similarities or differences. For instance, bacterial aggregates formed in MGP were reported to rely on the sticky nature of polymers produced by planktons (Rochelle-Newall et al., 2010); host secreted abundant polymers found in chronic infection sites may drive bacterial aggregation through entropic forces independent of biofilm formation (Secor et al., 2018); lectin-like protein in colon mucus binds to cell wall peptidoglycan and thus aggregates the bacteria that might otherwise cause inflammation if not kept at a safe distance from epithelium (Bergström et al., 2016). It seems that physical, chemical, and biological mechanisms may all be involved in polymer-induced bacteria aggregation. Are they all contributing to bacterial aggregation in different settings as generic mechanisms, or do different polymers act distinctly due to their specific nature? Are different bacterial proteins/polysaccharides playing important roles in how the aggregates are formed? While extensive investigations have been made towards how solid surfaces can change biofilm initiation and formation, future work may focus on the mechanisms of how different polymers influence bacterial aggregation. More efficient intervention strategies in chronic infection may then be applied to disperse or separate aggregates developed in mucus. Additionally, it may also help us to better design polymer used in medical settings such as dermal fillers, which have been shown to support bacterial aggregation (Alhede et al., 2014).

The overuse of antibiotics in human and animal husbandry is now widely acknowledged to generate antibiotic resistant strains and consequently lead to treatment failure. The formation of biofilms and aggregates adds another layer of complexity, both causing antibiotic tolerance (Olsen, 2015) and promoting horizontal resistant gene transfer (Madsen et al., 2012; Savage et al., 2013). While minimal inhibition and bactericidal concentrations are easy to identify in laboratories for either planktonic cells or biofilms from pure cultures, real-life situations are much more complicated and thus bring in another issue-treatment concentrations. Numerous reports showed that sublethal (sub-MIC) concentrations of antibiotics can actually promote biofilm formation in vitro (Kaplan, 2011; Andersson and Hughes, 2014), although the detailed mechanisms may vary and are yet to be clarified for different strains and compounds. A similar phenomenon is also found in freshwater bacterial isolates, where antibiotics can promote bacterial aggregation (Corno et al., 2014). Will the exposure to sub-MIC antibiotics lead to the growth of bacterial aggregates in vivo? Is the MIC for surface-attached biofilms the same for non-attached aggregates formed by the same strains? More direct evidence is required to confirm these speculation, and distinguishing aggregates from biofilms will more accurately guide the proper usage of antibiotics in clinical settings.

Are antibiotic resistance and biofilm tolerance totally negative? Antibiotics are documented to occur in aquatic environmental settings such as wastewater treatment plants, rivers, and lakes as a result of health care and animal husbandry, and this pollution can in turn accelerate the emergence of new antibiotic-resistant pathogens dangerous to human and animal health (Gothwal and Shashidhar, 2015). However, antibioticresistant strains were found to be retained in bacterial aggregates in the membrane biological reactors, serving a key function in facilitating the removal of antibiotic pharmaceuticals and personal care products in the wastewater (Xia et al., 2014). A list of antibiotic destructases have been found from environmental strains to inactivate different categories of antibiotics, of which some have also been found in human pathogens (Crofts et al., 2017; Markley and Wencewicz, 2018). Is it possible that we can 
use sludge intentionally seeded with antibiotic resistant strains or engineered enzymes to eliminate antibiotic pollutants in drinking water in the future? Will the mechanistic studies of antibiotic degradation lead to the development of novel adjunctive therapeutic agents that can suppress the antibiotic-resistance in clinically relevant pathogens, such as anhydrotetracycline that inhibits tetracycline destructase (Park et al., 2017)? Will these novel agents influence the development of aggregates at the same time with lowering antibiotic resistance? Much more awaits to be revealed, but the rich environmental bacteria reservoir never fails to surprise us-from the discovery of novel antibiotics, to the degradation of unwanted antibiotics.

In summary, non-surface attached bacterial aggregate are a secret masked ball full of excitement and opportunities to be explored. Thanks to the extensive studies in attached biofilms, lots of mechanistic pathways, treatments, and tools may also be applied for non-attached aggregates with some modifications. Nature has always inspired us for novel inventions and discoveries, which can also be the case in our understanding and co-inhabitation with the bacterial kingdom. Hence, more substantial research in environmental particles and flocs may inspire and facilitate clinical studies, now that we can demonstrate that aggregation not only happens in aquatic environmental settings, but also in CF mucus, wound infection

\section{REFERENCES}

Alfiansah, Y. R., Hassenrück, C., Kunzmann, A., Taslihan, A., Harder, J., and Gärdes, A. (2018). Bacterial abundance and community composition in pond water from shrimp aquaculture systems with different stocking densities. Front. Microbiol. 9:2457. doi: 10.3389/fmicb.2018.02457

Alhede, M., Er, Ö, Eickhardt, S., Kragh, K., Alhede, M., Christensen, L. D., et al. (2014). Bacterial biofilm formation and treatment in soft tissue fillers. Pathog. Dis. 70, 339-346. doi: 10.1111/2049-632X.12139

Alhede, M., Kragh, K. N., Qvortrup, K., Allesen-Holm, M., van Gennip, M., Christensen, L. D., et al. (2011). Phenotypes of non-attached Pseudomonas aeruginosa aggregates resemble surface attached biofilm. PLoS One 6:e27943.

Ali, M., Wang, Z., Salam, K. W., Hari, A. R., Pronk, M., van Loosdrecht, M. C. M., et al. (2019). Importance of species sorting and immigration on the bacterial assembly of different-sized aggregates in a full-scale aerobic granular sludge Plant. Environ. Sci. Technol. 14, 8291-8301. doi: 10.1021/acs.est.8b07303

Anderson, G. G., Dodson, K. W., Hooton, T. M., and Hultgren, S. J. (2004). Intracellular bacterial communities of uropathogenic Escherichia coli in urinary tract pathogenesis. Trends Microbiol. 12, 424-430. doi: 10.1016/j.tim.2004.07. 005

Andersson, D. I., and Hughes, D. (2014). Microbiological effects of sublethal levels of antibiotics. Nat. Rev. Microbiol. 12, 465-478. doi: 10.1038/nrmicro3270

Andreadakis, A. D. (1993). Physical and chemical properties of activated sludge floc. Water Res. 27, 1707-1714. doi: 10.1016/0043-1354(93)90107-S

Arcila, J. S., and Buitrón, G. (2017). Influence of solar irradiance levels on the formation of microalgae-bacteria aggregates for municipal wastewater treatment. Algal Res. 27, 190-197. doi: 10.1016/j.algal.2017.09.011

Arnosti, C., Durkin, S., and Jeffrey, W. H. (2005). Patterns of extracellular enzyme activities among pelagic marine microbial communities: implications for cycling of dissolved organic carbon. Aquat. Microb. Ecol. 38, 135-145. doi: 10.3354/ame038135

Arnosti, C., Ziervogel, K., Ocampo, L., and Ghobrial, S. (2009). Enzyme activities in the water column and in shallow permeable sediments from the northeastern Gulf of Mexico. Estuar. Coast. Shelf Sci. 84, 202-208. doi: 10.1016/j.ecss.2009. 06.018 sites and in other body fluids. Although much remains to be known, it is the aim of this review to bridge the gaps in knowledge that exist among researchers in different fields and shed light on some potential research directions for future work.

\section{AUTHOR CONTRIBUTIONS}

Y-MC did the bibliographic review and wrote the manuscript.

\section{FUNDING}

This work was funded by BBSRC and Innovate UK for National Biofilms Innovation Centre.

\section{ACKNOWLEDGMENTS}

The author would like to thank Dr. Sandra Wilks, Profs. Jeremy Webb, Bill Keevil, and Grant Burgess for the inspirations and fruitful discussions, as well as Dr. Catherine Bryant and Dr. John Finlay for scrutinising the grammar and content.

Ash, R. J., Mauck, B., and Morgan, M. (2002). Antibiotic resistance of gramnegative bacteria in rivers, United States. Emerg. Infect. Dis. 8, 713-716. doi: 10.3201/eid0807.010264

Azetsu-Scott, K., and Passow, U. (2004). Ascending marine particles: significance of transparent exopolymer particles (TEP) in the upper ocean. Limnol. Oceanogr. 49, 741-748. doi: 10.4319/lo.2004.49.3.0741

Bar-Zeev, E., and Rahav, E. (2015). Microbial metabolism of transparent exopolymer particles during the summer months along a eutrophic estuary system. Front. Microbiol. 6:403. doi: 10.3389/fmicb.2015.00403

Baugh, S., Phillips, C. R., Ekanayaka, A. S., Piddock, L. J. V., and Webber, M. A. (2014). Inhibition of multidrug efflux as a strategy to prevent biofilm formation. J. Antimicrob. Chemother. 69, 673-681. doi: 10.1093/jac/dkt420

Bergström, J. H., Birchenough, G. M., Katona, G., Schroeder, B. O., Schütte, A., Ermund, A., et al. (2016). Gram-positive bacteria are held at a distance in the colon mucus by the lectin-like protein ZG16. Proc. Natl. Acad. Sci. U.S.A. 113, 13833-13838. doi: 10.1073/pnas.1611400113

Bittar, T. B., Passow, U., Hamaraty, L., Bidle, K. D., and Harvey, E. L. (2018). An updated method for the calibration of transparent exopolymer particle measurements. Limnol. Oceanogr. Methods 16, 621-628. doi: 10.1002/lom3. 10268

Bitton, G. (2010). Wastewater Microbiology, Fourth Edn. Hoboken, NJ: Wiley. doi: 10.1002/9780470901243

Bjarnsholt, T., Alhede, M., Eickhardt-Sørensen, S. R., Moser, C., Kühl, M., Jensen, P. Ø, et al. (2013). The in vivo biofilm. Trends Microbiol. 21, 466-474. doi: 10.1016/j.tim.2013.06.002

Bjarnsholt, T., Jensen, P. Ø, Fiandaca, M. J., Pedersen, J., Hansen, C. R., Andersen, C. B., et al. (2009). Pseudomonas aeruginosa biofilms in the respiratory tract of cystic fibrosis patients. Pediatr. Pulmonol. 44, 547-558. doi: 10.1002/ppul. 21011

Böckelmann, U., Manz, W., Neu, T. R., and Szewzyk, U. (2000). Characterization of the microbial community of lotic organic aggregates ('river snow') in the Elbe River of Germany by cultivation and molecular methods. FEMS Microbiol. Ecol. 33, 157-170. doi: 10.1016/S0168-6496(00)00056-8

Briggs, N., Dall'Olmo, G., and Claustre, H. (2020). Major role of particle fragmentation in regulating biological sequestration of $\mathrm{CO} 2$ by the oceans. Science 367, 791-793. doi: 10.1126/science.aay1790 
Burns, W. G., Marchetti, A., and Ziervogel, K. (2019). Enhanced formation of transparent exopolymer particles (TEP) under turbulence during phytoplankton growth. J. Plankton Res. 41, 349-361. doi: 10.1093/plankt/ fbz018

Busch, K., Endres, S., Iversen, M. H., Michels, J., Nothig, E.-M., and Engel, A. (2017). Bacterial colonization and vertical distribution of marine gel particles (TEP and CSP) in the arctic Fram Strait. Front. Mar. Sci. 4:166. doi: 10.3389/ fmars.2017.00166

Caceres, S. M., Malcolm, K. C., Taylor-Cousar, J. L., Nichols, D. P., Saavedra, M. T., Bratton, D. L., et al. (2014). Enhanced in vitro formation and antibiotic resistance of nonattached Pseudomonas aeruginosa aggregates through incorporation of neutrophil products. Antimicrob. Agents Chemother. 58, 6851-6860. doi: 10.1128/AAC.03514-14

Cai, H., Jiang, H., Krumholz, L. R., and Yang, Z. (2014). Bacterial community composition of size-fractioned aggregates within the phycosphere of cyanobacterial blooms in a eutrophic freshwater lake. PLoS One 9:e102879. doi: 10.1371/journal.pone.0102879

Cai, Y. M., Chatelet, D. S., Howlin, R. P., Wang, Z., and Webb, J. S. (2019). A novel application of Gini coefficient for the quantitative measurement of bacterial aggregation. Sci. Rep. 9:19002. doi: 10.1038/s41598-019-55567-z

Campbell, B. J., and Kirchman, D. L. (2013). Bacterial diversity, community structure and potential growth rates along an estuarine salinity gradient. ISME J. 7, 210-220. doi: 10.1038/ismej.2012.93

Campodónico, V. L., Gadjeva, M., Paradis-Bleau, C., Uluer, A., and Pier, G. B. (2008). Airway epithelial control of Pseudomonas aeruginosa infection in cystic fibrosis. Trends Mol. Med. 14, 120-133. doi: 10.1016/j.molmed.2008.01.002

Collins, J. R., Edwards, B. R., Thamatrakoln, K., Ossolinski, J. E., DiTullio, G. R., Bidle, K. D., et al. (2015). The multiple fates of sinking particles in the North Atlantic Ocean. Global Biogeochem. Cycles 29, 1471-1494. doi: 10.1002/ 2014GB005037

Connell, J. L., Kim, J., Shear, J. B., Bard, A. J., and Whiteley, M. (2014). Realtime monitoring of quorum sensing in 3D-printed bacterial aggregates using scanning electrochemical microscopy. Proc. Natl. Acad. Sci. U.S.A. 111, 1825518260. doi: $10.1073 /$ pnas. 1421211111

Conover, M. S., Hadjifrangiskou, M., Palermo, J. J., Hibbing, M. E., Dodson, K. W., and Hulgren, S. J. (2016). Metabolic requirements of Escherichia coli in intracellular bacterial communities during urinary tract infection pathogenesis. mBio 7:e00104-16. doi: 10.1128/mBio.00104-16

Corno, G., Coci, M., Giardina, M., Plechuk, S., Campanile, F., and Stefani, S. (2014). Antibiotics promote aggregation within aquatic bacterial communities. Front. Microbiol. 5:297. doi: 10.3389/fmicb.2014.00297

Crofts, T. S., Gasparrini, A. J., and Dantas, G. (2017). Next-generation approaches to understand and combat the antibiotic resistome. Nat. Rev. Microbiol. 5, 422-434. doi: 10.1038/nrmicro.2017.28

Crump, B. C., Armbrust, E. V., and Baross, J. A. (1999). Phylogenetic analysis of particle-attached and free-living bacterial communities in the Columbia River, its estuary, and the adjacent coastal ocean. Appl. Environ. Microbiol. 65, 3192-3204.

Cunliffe, M., and Murrell, J. C. (2009). The sea-surface microlayer is a gelatinous biofilm. ISME J. 3, 1001-1003. doi: 10.1038/ismej.2009.69

Cunliffe, M., Salter, M., Mann, P. J., Whiteley, A. S., Upstill-Goddard, R. C., and Murrell, J. C. (2009a). Dissolved organic carbon and bacterial populations in the gelatinous surface microlayer of a Norwegian fjord mesocosm. FEMS Microbiol. Lett. 299, 248-254. doi: 10.1111/j.1574-6968.2009.01751.x

Cunliffe, M., Upstill-Goddard, R. C., and Murrell, J. C. (2011). Microbiology of aquatic surface microlayers. FEMS Microbiol. Rev. 35, 233-246. doi: 10.1111/j. 1574-6976.2010.00246.x

Cunliffe, M., Whiteley, A. S., Newbold, L., Oliver, A., Schäfer, H., and Murrell, J. C. (2009b). Comparison of bacterioneuston and bacterioplankton dynamics during a phytoplankton bloom in a fjord mesocosm. Appl. Environ. Microbiol. 75,7173-7181. doi: 10.1128/AEM.01374-09

Da Motta, M., Pons, M. N., Roche, N., and Vivier, H. (2001). Characterisation of activated sludge by automated image analysis. Biochem. Eng. J. 9, 165-173. doi: 10.1016/S1369-703X(01)00138-3

Daims, H., Lücker, S., and Wagner, M. (2006). daime, a novel image analysis program for microbial ecology and biofilm research. Environ. Microbiol. 8, 200-213. doi: 10.1111/j.1462-2920.2005.00880.x
Dalton, T., Dowd, S. E., Wolcott, R. D., Sun, Y., Watters, C., Griswold, J. A., et al. (2011). An in vivo polymicrobial biofilm wound infection model to study interspecies interactions. PLoS One 6:e27317. doi: 10.1371/journal.pone. 0027317

Darch, S. E., Kragh, K. N., Abbott, E. A., Bjarnsholt, T., Bull, J. J., and Whiteley, M. (2017). Phage inhibit pathogen dissemination by targeting bacterial migrants in a chronic infection model. mBio 8:e0240-17. doi: 10.1128/mBio.00240-17

Dastghey, S., Parvizi, J., Shapiro, I. M., Hickok, N. J., and Otto, M. (2015). Effect of biofilms on recalcitrance of Staphylococcal joint infection to antibiotic treatment. J. Infect. Dis. 211, 641-650. doi: 10.1093/infdis/jiu514

De Bentzmann, S., Plotkowski, C., and Puchelle, E. (1996). Receptors in the Pseudomonas aeruginosa adherence to injured and repairing airway epithelium. Am. J. Respir. Crit. Care Med. 154, S155-S162. doi: 10.1164/ajrccm/154.4_pt_2. s155

Deligianni, E., Pattison, S., Berrar, D., Ternan, N. G., Haylock, R. W., Moore, J. E., et al. (2010). Pseudomonas aeruginosa cystic fibrosis isolates of similar RAPD genotype exhibit diversity in biofilm forming ability in vitro. BMC Microbiol. 10:38. doi: 10.1186/1471-2180-10-38

DeLong, E. F., Franks, D. G., and Alldredge, A. L. (1993). Phylogenetic diversity of aggregate attached vs. free-living marine bacterial assemblages. Limnol. Oceanogr. 38, 924-934. doi: 10.4319/lo.1993.38.5.0924

Donaldson, G. P., Lee, S. M., and Mazmanian, S. K. (2015). Gut biogeography of the bacterial microbiota. Nat. Rev. Microbiol. 14, 20-32. doi: 10.1038/nrmicro3552

Engel, A. (2004). Distribution of transparent exopolymer particles (TEP) in the northeast Atlantic Ocean and their potential significance for aggregation processes. Deep. Res. Part I Oceanogr. Res. Pap. 51, 83-92. doi: 10.1016/j.dsr. 2003.09.001

Engel, A., Bange, H. W., Cunliffe, M., Burrows, S. M., Friedrichs, G., Galgani, L., et al. (2017). The ocean's vital skin: toward an integrated understanding of the sea surface microlayer. Front. Mar. Sci. 4:165. doi: 10.3389/fmars.2017.00165

Engel, A., and Galgani, L. (2016). The organic sea-surface microlayer in the upwelling region off the coast of Peru and potential implications for air-sea exchange processes. Biogeosciences 13, 989-1007. doi: 10.5194/bg-13-989-2016

Engel, A., and Schartau, M. (1999). Influence of transparent exopolymer particles (TEP) on sinking velocity of Nitzschia closterium aggregates. Mar. Ecol. Prog. Ser. 182, 69-76. doi: 10.3354/meps182069

Engel, A., Thoms, S., Riabesell, U., Rochelle-Newall, E., and Zondervan, I. (2004). Polysaccharide aggregation as a potential sink of marine dissolved organic carbon. Nature 428, 929-932. doi: 10.1038/nature02453

Enke, T. N., Leventhal, G. E., Metzger, M., Saavedra, J. T., and Cordero, O. X. (2018). Microscale ecology regulates particulate organic matter turnover in model marine microbial communities. Nat. Commun. 9:2743. doi: 10.1038/ s41467-018-05159-8

Ensgraber, M., and Loos, M. (1992). A 66-kilodalton heat shock protein of Salmonella typhimurium is responsible for binding of the bacterium to intestinal mucus. Infect. Immun. 60, 3072-3078.

Fazli, M., Bjarnsholt, T., Kirketerp-Møller, K., Jørgensen, B., Andersen, A. S., Krogfelt, K. A., et al. (2009). Nonrandom distribution of Pseudomonas aeruginosa and Staphylococcus aureus in chronic wounds. J. Clin. Microbiol. 47, 4084-4089. doi: 10.1128/JCM.01395-09

Flemming, H. C., Neu, T. R., and Wingender, J. (2016). "The perfect slime: microbial extracellular polymeric substances (EPS)," in Water Intelligence Online, London: IWA publishing. doi: 10.2166/9781780407425

Flemming, H. C., and Wuertz, S. (2019). Bacteria and archaea on Earth and their abundance in biofilms. Nat. Rev. Microbiol. 17, 247-260. doi: 10.1038/s41579019-0158-9

Flintrop, C. M., Rogge, A., Miksch, S., Thiele, S., Waite, A. M., and Iversen, M. H. (2018). Embedding and slicing of intact in situ collected marine snow. Limnol. Oceanogr. Methods 16, 339-355. doi: 10.1002/lom3.10251

Foladori, P., Bruni, L., Tamburini, S., and Ziglio, G. (2010). Direct quantification of bacterial biomass in influent, effluent and activated sludge of wastewater treatment plants by using flow cytometry. Water Res. 44, 3807-3818. doi: 10 . 1016/j.watres.2010.04.027

Foladori, P., Petrini, S., Nessenzia, M., and Andreottola, G. (2018). Enhanced nitrogen removal and energy saving in a microalgal-bacterial consortium treating real municipal wastewater. Water Sci. Technol. 78, 174-182. doi: 10 2166/wst.2018.094 
Foulston, L., Elsholz, A. K. W., DeFrancesco, A. S., and Losick, R. (2014). The extracellular matrix of Staphylococcus aureus biofilms comprises cytoplasmic proteins that associate with the cell surface in response to decreasing $\mathrm{pH}$. mBio 5:e01667-14. doi: 10.1128/mBio.01667-14

Franklin, M. P., McDonald, I. R., Bourne, D. G., Owens, N. J., Upstill-Goddard, R. C., and Murrell, J. C. (2005). Bacterial diversity in the bacterioneuston (sea surface microlayer): the bacterioneuston through the looking glass. Environ. Microbiol. 7, 723-736. doi: 10.1111/j.1462-2920.2004.00736.x

Fung, C., Naughton, S., Turnbull, L., Tingpej, P., Rose, B., Arthur, J., et al. (2010). Gene expression of Pseudomonas aeruginosa in a mucin-containing synthetic growth medium mimicking cystic fibrosis lung sputum. J. Med. Microbiol. 59, 1089-1100. doi: 10.1099/jmm.0.019984-0

Galgani, L., and Engel, A. (2013). Accumulation of gel particles in the seasurface microlayer during an experimental study with the diatom Thalassiosira weissflogii. Int. J. Geosci. 4, 129-145. doi: 10.4236/ijg.2013.41013

Garcia-Medina, R., Dunne, W. M., Singh, P. K., and Brody, S. L. (2005). Pseudomonas aeruginosa acquires biofilm-like properties within airway epithelial cells. Infect. Immun. 73, 8298-8305. doi: 10.1128/IAI.73.12.82988305.2005

Gernaey, K. V., and Sin, G. (2008). Wastewater Treatment Models. Encycl. Ecol. 5, 3705-3718. doi: 10.1016/b978-008045405-4.00828-4

Gershey, R. M. (1983). Characterization of seawater organic matter carried by bubble-generated aerosols. Limnol. Oceanogr. 28, 309-319. doi: 10.4319/lo. 1983.28.2.0309

Gilbertie, J. M., Schnabel, L. V., Hickok, N. J., Jacob, M. E., Conlon, B. P., Shapiro, I. M., et al. (2019). Equine or porcine synovial fluid as a novel ex vivo model for the study of bacterial free-floating biofilms that form in human joint infections. PLoS One 14:e0221012. doi: 10.1371/journal.pone.0221012

Golub, E. E., Cheruka, J., Boosz, B., Davis, C., and Malamud, D. (1985). A comparison of bacterial aggregation induced by saliva, lysozyme, and zinc. Infect. Immun. 48, 204-210.

Gothwal, R., and Shashidhar, T. (2015). Antibiotic pollution in the environment: a review. Clean Soil Air Water 43, 479-489. doi: 10.1002/clen.201300989

Gram, L., Grossart, H. P., Schlingloff, A., and Kiørboe, T. (2002). Possible quorum sensing in marine snow bacteria: production of acylated homoserine lactones by Roseobacter strains isolated from marine snow. Appl. Environ. Microbiol. 68, 4111-4116. doi: 10.1128/AEM.68.8.4111-4116.2002

Grassi, L., Batoni, G., Ostyn, L., Rigole, P., Van den Bossche, S., Rinaldi, A. C., et al. (2019). The antimicrobial peptide lin-SB056-1 and its dendrimeric derivative prevent Pseudomonas aeruginosa biofilm formation in physiologically relevant models of chronic infections. Front. Microbiol. 10:198. doi: 10.3389/fmicb.2019. 00198

Grossart, H. P., and Simon, M. (1993). Limnetic macroscopic organic aggregates (lake snow): occurrence, characteristics, and microbial dynamics in Lake Constance. Limnol. Oceanogr. 38, 532-546. doi: 10.4319/lo.1993.38.3.0532

Grossart, H. P., and Simon, M. (1998b). Significance of limnetic organic aggregates (lake snow) for the sinking flux of particulate organic matter in a large lake. Aquat. Microb. Ecol. 15, 115-125. doi: 10.3354/ame015115

Grossart, H. P., and Simon, M. (1998a). Bacterial colonization and microbial decomposition of limnetic organic aggregates (lake snow). Aquat. Microb. Ecol. 15, 127-140. doi: 10.3354/ame015127

Guo, A., Xu, Y., Mowery, J., Nagy, A., Bauchan, G., and Nou, X. (2016). Ralstonia insidiosa induces cell aggregation of Listeria monocytogenes. Food Control 67, 303-309. doi: 10.1016/j.foodcont.2016.03.006

Guo, Y., Liu, M., Liu, L., Liu, X., Chen, H., and Yang, J. (2018). The antibiotic resistome of free-living and particle-attached bacteria under a reservoir cyanobacterial bloom. Environ. Int. 117, 107-115. doi: 10.1016/j.envint.2018. 04.045

Gutzeit, G., Lorch, D., Weber, A., Engels, M., and Neis, U. (2005). Bioflocculent algal-bacterial biomass improves low-cost wastewater treatment. Water Sci. Technol. 52, 9-18. doi: 10.2166/wst.2005.0415

Hahn, H. P. (1997). The type-4 pilus is the major virulence-associated adhesin of Pseudomonas aeruginosa - a review. Gene 192, 99-108.

Hall-Stoodley, L., Stoodley, P., Kathju, S., Høiby, N., Moser, C., Costerton, J. W., et al. (2012). Towards diagnostic guidelines for biofilm-associated infections. FEMS Immunol. Med. Microbiol. 65, 127-145. doi: 10.1111/j.1574-695X.2012. 00968.x
Hartmann, R., Jeckel, H., Jelli, E., Singh, P. K., Vaidya, S., Bayer, M., et al. (2019). BiofilmQ, a software tool for quantitative image analysis of microbial biofilm communities. bioRxiv [Preprint]. doi: 10.1101/735423

Hassett, D. J., Cuppoletti, J., Trapnell, B., Lymar, S. V., Rowe, J. J., Yoon, S. S., et al. (2002). Anaerobic metabolism and quorum sensing by Pseudomonas aeruginosa biofilms in chronically infected cystic fibrosis airways: rethinking antibiotic treatment strategies and drug targets. Adv. Drug Deliv. Rev. 54, 1425-1443.

He, Q., Zhou, J., Wang, H., Zhang, J., and Wei, L. (2016). Microbial population dynamics during sludge granulation in an $\mathrm{A} / \mathrm{O} / \mathrm{A}$ sequencing batch reactor. Bioresour. Technol. 214, 1-8. doi: 10.1016/j.biortech.2016.04.088

Herndl, G. J., and Reinthaler, T. (2013). Microbial control of the dark end of the biological pump. Nat. Geosci. 6, 718-724. doi: 10.1038/ngeo1921

Heydorn, A., Nielsen, A. T., Hentzer, M., Sternberg, C., Givskov, M., Ersbøll, B. K., et al. (2000). Quantification of biofilm structures by the novel computer program COMSTAT. Microbiology 146, 2395-2407. doi: 10.1099/00221287146-10-2395

Høiby, N. (2017). A short history of microbial biofilms and biofilm infections. APMIS 125, 272-275. doi: 10.1111/apm.12686

Huisman, J., Codd, G. A., Paerl, H. W., Ibelings, B. W., Verspagen, J. M. H., and Visser, P. M. (2018). Cyanobacterial blooms. Nat. Rev. Microbiol. 16, 471-483. doi: 10.1038/s41579-018-0040-1

Imundo, L., Barasch, J., Prince, A., and Al-Awqati, Q. (1995). Cystic fibrosis epithelial cells have a receptor for pathogenic bacteria on their apical surface. Proc. Natl. Acad. Sci. U.S.A. 92, 3019-3023.

Itzek, A., Chen, Z., Merritt, J., and Kreth, J. (2017). Effect of salivary agglutination on oral streptococcal clearance by human polymorphonuclear neutrophil granulocytes. Mol. Oral Microbiol. 32, 197-210. doi: 10.1111/omi.12164

Ivancic, I., Paliaga, P., Pfannkuchen, M., Djakovac, T., Najdek, M., Steiner, P., et al. (2018). Seasonal variations in extracellular enzymatic activity in marine snowassociated microbial communities and their impact on the surrounding water. FEMS Microbiol. Ecol. 94:12. doi: 10.1093/femsec/fiy198

Jagmann, N., Henke, S. F., and Philipp, B. (2015). Cells of Escherichia coli are protected against severe chemical stress by co-habiting cell aggregates formed by Pseudomonas aeruginosa. Appl. Microbiol. Biotechnol. 99, 8285-8294. doi: 10.1007/s00253-015-6726-7

James, G. A., Swogger, E., Wolcott, R., Pulcini, E., Secor, P., Sestrich, J., et al. (2008). Biofilms in chronic wounds. Wound Repair Regen. 16, 37-44. doi: 10.1111/j. 1524-475X.2007.00321.x

Jin, B., Wilén, B. M., and Lant, P. (2003). A comprehensive insight into floc characteristics and their impact on compressibility and settleability of activated sludge. Chem. Eng. J. 95, 221-234. doi: 10.1016/S1385-8947(03)00108-6

Johnson, B. D., and Cooke, R. C. (1980). Organic particle and aggregate formation resulting from the dissolution of bubbles in seawater. Limnol. Oceanogr. 25, 653-661. doi: 10.4319/lo.1980.25.4.0653

Jorand, F., Zartarian, F., Thomas, F., Block, J. C., Bottero, J. Y., Villemin, G., et al. (1995). Chemical and structural (2D) linkage between bacteria within activated sludge flocs. Water Res. 29, 1639-1647. doi: 10.1016/0043-1354(94)00350-G

Jung, Y. G., Choi, J., Kim, S. K., Lee, J. H., and Kwon, S. (2015). Embedded biofilm, a new biofilm model based on the embedded growth of bacteria. Appl. Environ. Microbiol. 81, 211-219. doi: 10.1128/AEM.02311-14

Justice, S. S., Hung, C., Theriot, J. A., Fletcher, D. A., Anderson, G. G., Footer, M. J., et al. (2004). Differentiation and developmental pathways of uropathogenic Escherichia coli in urinary tract pathogenesis. Proc. Natl. Acad. Sci. U.S.A. 101, 1333-1338. doi: 10.1073/pnas.0308125100

Kantha, L. H., and Anne Clayson, C. (2004). On the effect of surface gravity waves on mixing in the oceanic mixed layer. Ocean Model. 6, 101-124. doi: 10.1016/S1463-5003(02)00062-8

Kaplan, J. B. (2011). Antibiotic-induced biofilm formation. Int. J. Artif. Organs 34, 737-751. doi: 10.5301/ijao.5000027

Kara, F., Gurakan, G. C., and Sanin, F. D. (2008). Monovalent cations and their influence on activated sludge floc chemistry, structure, and physical characteristics. Biotechnol. Bioeng. 100, 231-239. doi: 10.1002/bit.21755

Kim, T. W., Joung, Y., Han, J. H., Jung, W., and Kim, S. B. (2015). Antibiotic resistance among aquatic bacteria in natural freshwater environments of Korea. J. Water Health 13, 1085-1097. doi: 10.2166/wh.2015.032

Kinnunen, V., and Rintala, J. (2016). The effect of low-temperature pretreatment on the solubilization and biomethane potential of microalgae biomass grown in 
synthetic and wastewater media. Bioresour. Technol. 221, 78-84. doi: 10.1016/j. biortech.2016.09.017

Kirchman, D. (1983). The production of bacteria attached to particles suspended in a freshwater pond. Limnol. Oceanogr. 28, 858-872. doi: 10.4319/lo.1983.28.5. 0858

Kirketerp-Møller, K., Jensen, P. Ø, Fazli, M., Madsen, K. G., Pedersen, J., and Moser, C. (2008). Distribution, organization, and ecology of bacteria in chronic wounds. J. Clin. Microbiol. 46, 2717-2722. doi: 10.1128/JCM.00501-08

Kitada, K., and Oho, T. (2012). Effect of saliva viscosity on the co-aggregation between oral Streptococci and Actinomyces naeslundii. Gerodontology 29, e981e987. doi: 10.1111/j.1741-2358.2011.00595.x

Koop, H. M., Valentijn-Benz, M., Nieuw Amerongen, A. V., Roukema, P. A., and De Graaff, J. (1989). Aggregation of 27 oral bacteria by human whole saliva. Antonie Van Leeuwenhoek 55, 277-290. doi: 10.1007/bf00393856

Larsen, P., Nielsen, J. L., Otzen, D., and Nielsen, P. H. (2008). Amyloid-like adhesins produced by floc-forming and filamentous bacteria in activated sludge. Appl. Environ. Microbiol. 74, 1517-1526. doi: 10.1128/AEM.02274-07

Lee, B., Haagensen, J. A., Ciofu, O., Andersen, J. B., Høiby, N., Molin, S., et al. (2005). Heterogeneity of biofilms formed by nonmucoid Pseudomonas aeruginosa isolates from patients with cystic fibrosis. J. Clin. Microbiol. 43 5247-5255. doi: 10.1128/JCM.43.10.5247-5255.2005

Lee, J., Cho, D.-H., Ramanan, R., Kim, B.-H., Oh, H.-M., and Kim, H.-S. (2013). Microalgae-associated bacteria play a key role in the flocculation of Chlorella vulgaris. Bioresour. Technol. 131, 195-201. doi: 10.1016/j.biortech.2012.11.130

Long, R. A., and Azam, F. (1996). Abundant protein-containing particles in the sea. Aquat. Microb. Ecol. 10, 213-221. doi: 10.3354/ame010213

Lu, S., Chourey, K., Reiche, M., Nietzsche, S., Shah, M. B., Neu, T. R., et al. (2013). Insights into the structure and metabolic function of microbes that shape pelagic iron-rich aggregates ('Iron snow'). Appl. Environ. Microbiol. 79, 4272-4281. doi: 10.1128/AEM.00467-13

Ma, L., Conover, M., Lu, H., Parsek, M. R., Bayles, K., and Wozniak, D. J. (2009). Assembly and development of the Pseudomonas aeruginosa biofilm matrix. PLoS Pathog. 5:e1000354.

Madsen, J. S., Burmølle, M., Hansen, L. H., and Sørensen, S. J. (2012). The interconnection between biofilm formation and horizontal gene transfer. FEMS Immunol. Med. Microbiol. 65, 183-195. doi: 10.1111/j.1574-695X.2012.00960.x

Malik, A., Sakamoto, M., Hanazaki, S., Osawa, M., Suzuki, T., Tochigi, M., et al. (2003). Coaggregation among nonflocculating bacteria isolated from activated sludge. Appl. Environ. Microbiol. 69, 6056-6063. doi: 10.1128/AEM.69.10.60566063.2003

Mari, X., and Kiørboe, T. (1996). Abundance, size distribution and bacterial colonization of transparent exopolymeric particles (TEP) during spring in the Kattegat. J. Plankton Res. 18, 969-986. doi: 10.1093/plankt/18.6.969

Mari, X., Passow, U., Migon, C., Burd, A. B., and Legendre, L. (2017). Transparent exopolymer particles: effects on carbon cycling in the ocean. Prog. Oceanogr. 151, 13-37. doi: 10.1016/j.pocean.2016.11.002

Markley, J. L., and Wencewicz, T. A. (2018). Tetracycline-inactivating enzymes. Front. Microbiol. 9:1058. doi: 10.3389/fmicb.2018.01058

Mezhoud, N., Zili, F., Bouzidi, N., Helaoui, F., Ammar, J., and Ouada, H. B. (2014). The effects of temperature and light intensity on growth, reproduction and EPS synthesis of a thermophilic strain related to the genus Graesiella. Bioprocess Biosyst. Eng. 37, 2271-2280. doi: 10.1007/s00449-014-1204-7

Michaels, A. F., Bates, N. R., Buesseler, K. O., Carlson, C. A., and Knap, A. H. (1994). Carbon-cycle imbalances in the Sargasso Sea. Nature 372, 537-540. doi: $10.1038 / 372537 \mathrm{a} 0$

Morgan, S. J., Lippman, S. I., Bautista, G. E., Harrison, J. J., Harding, C. L., Gallagher, L. A., et al. (2019). Bacterial fitness in chronic wounds appears to be mediated by the capacity for high-density growth, not virulence or biofilm functions. PLoS Pathog. 15:e1007511. doi: 10.1371/journal.ppat.1007511

Mori, J. F., Ueberschaar, N., Lu, S., Cooper, R. E., Pohnert, G., and Küsel, K. (2017). Sticking together: inter-species aggregation of bacteria isolated from iron snow is controlled by chemical signaling. ISME J. 1, 1075-1086. doi: 10.1038/ismej. 2016.186

Mulvey, M. A., Schilling, J. D., and Hultgren, S. J. (2001). Establishment of a persistent Escherichia coli reservoir during the acute phase of a bladder infection. Infect. Immun. 69, 4572-4579. doi: 10.1128/IAI.69.7.4572-4579. 2001
Nancharaiah, Y. V., and Kiran Kumar Reddy, G. (2018). Aerobic granular sludge technology: mechanisms of granulation and biotechnological applications. Bioresour. Technol. 247, 1128-1143. doi: 10.1016/j.biortech.2017.09.131

Nascimento, A. L., Souza, A. J., Andrade, P. A. M., Andreote, F. D., Coscione, A. R., Oliveira, F. C., et al. (2018). Sewage sludge microbial structures and relations to their sources, treatments, and chemical attributes. Front. Microbiol. 9:1462. doi: $10.3389 /$ fmicb. 2018.01462

Neu, T. R. (2000). In situ cell and glycoconjugate distribution in river snow studied by confocal laser scanning microscopy. Aquat. Microb. Ecol. 21, 85-95. doi: 10.3354/ame021085

Nickel, J. C., Ruseska, I., Wright, J. B., and Costerton, J. W. (1985). Tobramycin resistance of Pseudomonas aeruginosa cells growing as a biofilm on urinary catheter material. Antimicrob. Agents Chemother. 27, 619-624. doi: 10.1128/ AAC.27.4.619

Nielsen, P. H., Mielczarek, A. T., Kragelund, C., Nielsen, J. L., Saunders, A. M., Kong, Y., et al. (2010). A conceptual ecosystem model of microbial communities in enhanced biological phosphorus removal plants. Water Res. 44, 5070-5088. doi: 10.1016/j.watres.2010.07.036

Nielsen, P. H., Thomsen, T. R., and Nielsen, J. L. (2004). Bacterial composition of activated sludge - Importance for floc and sludge properties. Water Sci. Technol. 49, 51-58. doi: 10.2166/wst.2004.0606

Nnadozie, C. F., and Odume, O. N. (2019). Freshwater environments as reservoirs of antibiotic resistant bacteria and their role in the dissemination of antibiotic resistance genes. Environ. Pollut. 254:113067. doi: 10.1016/j.envpol.2019. 113067

Obernosterer, I., Catala, P., Lami, R., Caparros, J., Ras, J., Bricaud, A., et al. (2008). Biochemical characteristics and bacterial community structure of the sea surface microlayer in the South Pacific Ocean. Biogeosciences 5, 693-705. doi: 10.5194/bg-5-693-2008

Ollion, J., Cochennec, J., Loll, F., Escudé, C., and Boudier, T. (2013). TANGO: a generic tool for high-throughput 3D image analysis for studying nuclear organization. Bioinformatics 29, 1840-1841. doi: 10.1093/bioinformatics/ btt276

Olsen, I. (2015). Biofilm-specific antibiotic tolerance and resistance. Eur. J. Clin. Microbiol. Infect. Dis. 34, 877-886. doi: 10.1007/s10096-015-2323-z

Ortega-Retuerta, E., Passow, U., Duarte, C. M., and Reche, I. (2009a). Effects of ultraviolet B radiation on (not so) transparent exopolymer particles. Biogeosciences 6, 3071-3080. doi: 10.5194/bg-6-3071-2009

Ortega-Retuerta, E., Reche, I., Pulido-Villena, E., Agustí, S., and Duarte, C. M. (2009b). Uncoupled distributions of transparent exopolymer particles (TEP) and dissolved carbohydrates in the Southern Ocean. Mar. Chem. 115, 59-65. doi: 10.1016/j.marchem.2009.06.004

O’Toole, G. A. (2011). Microtiter dish biofilm formation assay. J. Vis. Exp. 30:2437. doi: $10.3791 / 2437$

Pabst, B., Pitts, B., Lauchnor, E., and Stewart, P. S. (2016). Gel-entrapped Staphylococcus aureus bacteria as models of biofilm infection exhibit growth in dense aggregates, oxygen limitation, antibiotic tolerance, and heterogeneous gene expression. Antimicrob. Agents Chemother. 60, 6294-6301. doi: 10.1128/ AAC.01336-16

Park, J., Gasparrini, A. J., Reck, M. R., Symister, C. T., Elliott, J. L., Vogel, J. P., et al. (2017). Plasticity, dynamics, and inhibition of emerging tetracycline resistance enzymes. Nat. Chem. Biol. 13, 730-736. doi: 10.1038/nchembio.2376

Passow, U. (2002b). Transparent exopolymer particles (TEP) in aquatic environments. Prog. Oceanogr. 55, 287-333. doi: 10.1016/S0079-6611(02) 00138-6

Passow, U. (2002a). Production of transparent exopolymer particles (TEP) by phyto- and bacterioplankton. Mar. Ecol. Prog. Ser. 236, 1-12. doi: 10.3354/ meps 236001

Passow, U., and Carlson, C. A. (2012). The biological pump in a high CO2 world. Mar. Ecol. Prog. Ser. 470, 249-271. doi: 10.3354/meps09985

Passow, U., Murray, R. F. S. A., Pak, D. K., Brzezinski, M. A., and Alldredge, A. L. (2001). The origin of transparent exopolymer particles (TEP) and their role in the sedimentation of particulate matter. Cont. Shelf Res. 21, 327-346. doi: 10.1016/S0278-4343(00)00101-1

Proia, L., Anzil, A., Subirats, J., Borrego, C., Farrè, M., Llorca, M., et al. (2018). Antibiotic resistance along an urban river impacted by treated wastewaters. Sci. Total Environ. 62, 453-466. doi: 10.1016/j.scitotenv.2018.02.083 
Quijano, G., Arcila, J. S., and Buitrón, G. (2017). Microalgal-bacterial aggregates: applications and perspectives for wastewater treatment. Biotechnol. Adv. 35, 772-781. doi: 10.1016/j.biotechadv.2017.07.003

Raszka, A., Chorvatova, M., and Wanner, J. (2006). The role and significance of extracellular polymers in activated sludge. Part I: literature review. Acta Hydrochim. Hydrobiol. 34, 411-424. doi: 10.1002/aheh.200500640

Reiche, M., Lu, S., Ciobotă, V., New, T. R., Nietzsche, S., Rösch, P., et al. (2011). Pelagic boundary conditions affect the biological formation of iron-rich particles (iron snow) and their microbial communities. Limnol. Oceanogr. 56, 1386-1398. doi: 10.4319/lo.2011.56.4.1386

Reid, G., Bruce, A. W., Llano, M., McGroarty, J. A., and Blake, M. (1990). Bacterial aggregation in sepsis. Curr. Microbiol. 20, 185-190. doi: 10.1007/BF02091995

Robino, L., Scavone, P., Araujo, L., Algorta, G., Zunino, P., and Pírez, M. C. (2014). Intracellular bacteria in the pathogenesis of Escherichia coli urinary tract infection in children. Clin. Infect. Dis. 59, e158-e164. doi: 10.1093/cid/ciu634

Rochelle-Newall, E. J., Mari, X., and Pringault, O. (2010). Sticking properties of transparent exopolymeric particles (TEP) during aging and biodegradation. J. Plankton Res. 32, 1433-1442. doi: 10.1093/plankt/fbq060

Rosan, B., Appelbaum, B., Golub, E., Malamud, D., and Mandel, I. D. (1982). Enhanced saliva-mediated bacterial aggregation and decreased bacterial adhesion in caries-resistant versus caries-susceptible individuals. Infect. Immun. 38, 1056-1059.

Rosen, D. A., Hooton, T. M., Stamm, W. E., Humphrey, P. A., and Hultgren, S. J. (2007). Detection of intracellular bacterial communities in human urinary tract infection. PLoS Med. 4:e329. doi: 10.1371/journal.pmed.0040329

Rossello-Mora, R. A., Wagner, M., Amann, R., and Schleifer, K. H. (1995). The abundance of Zoogloea ramigera in sewage treatment plants. Appl. Environ. Microbiol. 61, 702-707.

Sambrotto, R. N., Savidge, G., Robinson, C., Boyd, P., Takahashi, T., Karl, D. M., et al. (1993). Elevated consumption of carbon relative to nitrogen in the surface ocean. Nature 363, 248-250. doi: 10.1038/363248a0

Sanin, F. D., and Vesilind, P. A. (1996). Synthetic sludge: a physical/chemical model in understanding bioflocculation. Water Environ. Res. 68, 927-933. doi: $10.2175 / 106143096 \times 127938$

Savage, V. J., Chopra, I., and O'Neill, A. J. (2013). Staphylococcus aureus biofilms promote horizontal transfer of antibiotic resistance. Antimicrob. Agents Chemother. 57, 1968-1970. doi: 10.1128/AAC.02008-12

Schartau, M., Engel, A., Schröter, J., Thoms, S., Völker, C., and Wolf-Gladrow, D. (2007). Modelling carbon overconsumption and the formation of extracellular particulate organic carbon. Biogeosciences 4, 433-454. doi: 10.5194/bg-4-4332007

Schleheck, D., Barraud, N., Klebensberger, J., Webb, J. S., McDougald, D., and Rice, S. A. (2009). Pseudomonas aeruginosa PAO1 preferentially grows as aggregates in liquid batch cultures and disperses upon starvation. PLoS One 4:e5513. doi: 10.1371/journal.pone.0005513

Schwartz, D. J., Chen, S. L., Hultgren, S. J., and Seed, P. C. (2011). Population dynamics and niche distribution of uropathogenic Escherichia coli during acute and chronic urinary tract infection. Infect. Immun. 79, 4250-4259. doi: 10.1128/ IAI.05339- 11

Secor, P. R., Michaels, L. A., Ratjen, A., Jennings, L. K., and Singh, P. K. (2018). Entropically driven aggregation of bacteria by host polymers promotes antibiotic tolerance in Pseudomonas aeruginosa. Proc. Natl. Acad. Sci. U.S.A. 115, 10780-10785. doi: 10.1073/pnas.1806005115

Shao, Y., Chung, B. S., Lee, S. S., Park, W., Lee, S. S., and Jeon, C. O. (2009). Zoogloea caeni sp. nov., a floc-forming bacterium isolated from activated sludge. Int. J. Syst. Evol. Microbiol. 59, 526-530. doi: 10.1099/ijs.0.65670-0

Shen, Y., Fan, Z., Chen, C., and Xu, X. (2015). An auto-flocculation strategy for Chlorella vulgaris. Biotechnol. Lett. 37, 75-80. doi: 10.1007/s10529-0141655-6

Sheng, G. P., Yu, H. Q., and Li, X. Y. (2010). Extracellular polymeric substances (EPS) of microbial aggregates in biological wastewater treatment systems: a review. Biotechnol. Adv. 28, 882-894. doi: 10.1016/j.biotechadv.2010.08.001

Sieburth, J. M. (1983). Microbiological and organic-chemical processes in the surface and mixed layers. Airsea Exch. Gases Part 108, 121-172. doi: 10.1007/ 978-94-009-7169-1_3

Simon, M., Alldredge, A., and Azam, F. (1990). Bacterial carbon dynamics on marine snow. Mar. Ecol. Prog. Ser. 65, 205-211. doi: 10.3354/meps065205
Snidaro, D., Zartarian, F., Jorand, F., Bottero, J.-Y., Block, J.-C., and Manem, J. (1997). Characterization of activated sludge flocs structure. Water Sci. Technol. 36, 313-320. doi: 10.1016/S0273-1223(97)00447-2

Sønderholm, M., Kragh, K. N., Koren, K., Jakobsen, T. H., Darch, S. E., Alhede, M., et al. (2017). Pseudomonas aeruginosa aggregate formation in an alginate bead Model system exhibits in vivo-like characteristics. Appl. Environ. Microbiol. 83:e00113-17. doi: 10.1128/aem.00113-17

Sponza, D. T. (2002). Extracellular polymer substances and physicochemical properties of flocs in steady- and unsteady-state activated sludge systems. Process Biochem. 37, 983-998. doi: 10.1016/S0032-9592(01)00306-5

Sriramulu, D. D. (2010). Amino acids enhance adaptive behaviour of Pseudomonas aeruginosa in the Cystic Fibrosis lung environment. Microbiol. Insights 3, 17-26. doi: $10.4137 / \mathrm{mbi} . s 4694$

Sriramulu, D. D., Lunsdorf, H., Lam, J. S., and Romling, U. (2005). Microcolony formation: a novel biofilm model of Pseudomonas aeruginosa for the cystic fibrosis lung. J. Med. Microbiol. 54, 667-676. doi: 10.1099/jmm.0. 45969-0

Staudinger, B. J., Muller, J. F., Halldórsson, S., Boles, B., Angermeyer, A., Nguyen, D., et al. (2014). Conditions associated with the cystic fibrosis defect promote chronic Pseudomonas aeruginosa infection. Am. J. Respir. Crit. Care Med. 189, 812-824. doi: 10.1164/rccm.201312-2142OC

Stocker, R., and Seymour, J. R. (2012). Ecology and physics of bacterial chemotaxis in the Ocean. Microbiol. Mol. Biol. Rev. 76, 792-812. doi: 10.1128/mmbr.0002912

Stoderegger, K. E., and Herndl, G. J. (1999). Production of exopolymer particles by marine bacterioplankton under contrasting turbulence conditions. Mar. Ecol. Prog. Ser. 189, 9-16. doi: 10.3354/meps189009

Stolle, C., Labrenz, M., Meeske, C., and Jürgens, K. (2011). Bacterioneuston community structure in the southern baltic sea and its dependence on meteorological conditions. Appl. Environ. Microbiol. 77, 3726-3733. doi: 10. 1128/AEM.00042-11

Stoodley, P., Wilson, S., Hall-Stoodley, L., Boyle, J. D., Lappin-Scott, H. M., Costerton, J. W., et al. (2001). Growth and detachment of cell clusters from mature mixed-species biofilms. Appl. Environ. Microbiol. 67, 5608-5613. doi: 10.1128/AEM.67.12.5608-5613.2001

Su, Y., Mennerich, A., and Urban, B. (2011). Municipal wastewater treatment and biomass accumulation with a wastewater-born and settleable algal-bacterial culture. Water Res. 45, 3351-3358. doi: 10.1016/j.watres.2011.03.046

Sugimoto, K., Fukuda, H., Baki, M. A., and Koike, I. (2007). Bacterial contributions to formation of transparent exopolymer particles (TEP) and seasonal trends in coastal waters of Sagami Bay. Japan. Aquat. Microb. Ecol. 46, 31-41. doi: 10.3354/ame046031

Świątczak, P., and Cydzik-Kwiatkowska, A. (2018). Performance and microbial characteristics of biomass in a full-scale aerobic granular sludge wastewater treatment plant. Environ. Sci. Pollut. Res. 25, 1655-1669. doi: 10.1007/s11356017-0615-9

Szabó, E., Liébana, R., Hermansson, M., Modin, O., Persson, F., and Wilén, B.-M. (2017). Microbial population dynamics and ecosystem functions of anoxic/aerobic granular sludge in sequencing batch reactors operated at different organic loading rates. Front. Microbiol. 8:770. doi: 10.3389/fmicb.2017. 00770

Taylor, J. D., Cottingham, S. D., Billinge, J., and Cunliffe, M. (2014). Seasonal microbial community dynamics correlate with phytoplankton-derived polysaccharides in surface coastal waters. ISME J. 8, 245-248. doi: 10.1038/ ismej.2013.178

Thiele, S., Fuchs, B. M., Amann, R., and Iversen, M. H. (2015). Colonization in the photic zone and subsequent changes during sinking determine bacterial community composition in marine snow. Appl. Environ. Microbiol. 81, 14631471. doi: 10.1128/AEM.02570-14

Thornton, D. C. O. (2018). Coomassie stainable particles (CSP): protein containing exopolymer particles in the ocean. Front. Mar. Sci. 5:206. doi: 10.3389/fmars. 2018.00206

Trunk, T., Khalil, H. S., and Leo, J. C. (2018). Bacterial autoaggregation. AIMS Microbiol. 4, 140-164. doi: 10.3934/microbiol.2018.1.140

Urbain, V., Block, J. C., and Manem, J. (1993). Bioflocculation in activated sludge: an analytic approach. Water Res. 27, 829-838. doi: 10.1016/0043-1354(93) 90147-A 
Van Oostende, N., Harlay, J., Vanelslander, B., Chou, L., Vyverman, W., and Sabbe, K. (2012). Phytoplankton community dynamics during late spring coccolithophore blooms at the continental margin of the Celtic Sea (North East Atlantic, 2006-2008). Prog. Oceanogr. 104, 1-16. doi: 10.1016/j.pocean.2012.04. 016

Vandamme, D., Muylaert, K., Fraeye, I., and Foubert, I. (2014). Floc characteristics of Chlorella vulgaris: influence of flocculation mode and presence of organic matter. Bioresour. Technol. 151, 383-387. doi: 10.1016/j.biortech.2013.09.112

Wang, X., Chen, Z., Kang, J., Zhao, X., and Shen, J. (2018). Removal of tetracycline by aerobic granular sludge and its bacterial community dynamics in SBR. RSC Adv. 8, 18284-18293. doi: 10.1039/c8ra01357h

Wang, X. C., Shen, J. M., Chen, Z l, Zhao, X., and Xu, H. (2016). Removal of pharmaceuticals from synthetic wastewater in an aerobic granular sludge membrane bioreactor and determination of the bioreactor microbial diversity. Appl. Microbiol. Biotechnol. 100, 8213-8223. doi: 10.1007/s00253-016-7577-6

Watters, C., DeLeon, K., Trivedi, U., Griswold, J. A., Lyte, M., Hampel, K. J., et al. (2013). Pseudomonas aeruginosa biofilms perturb wound resolution and antibiotic tolerance in diabetic mice. Med. Microbiol. Immunol. 202, 131-141. doi: 10.1007/s00430-012-0277-7

Weiss, P., Schweitzer, B., Amann, R., and Simon, M. (1996). Identification in situ and dynamics of bacteria on limnetic organic aggregates (lake snow). Appl. Environ. Microbiol. 62, 1998-2005.

Wessel, A. K., Arshad, T. A., Fitzpatrick, M., Connell, J. L., Bonnecaze, R. T., Shear, J. B., et al. (2014). Oxygen limitation within a bacterial aggregate. mBio 5:e00992-14. doi: 10.1128/mBio.00992-14

Wilen, B. M., and Balmer, P. (1999). Effect of dissolved oxygen concentration on the structure, size and size distribution of activated sludge flocs. Doktorsavhandlingar Chalmers Tek. Hogsk. 33, 391-400. doi: 10.1016/S00431354(98)00208-5

Wilén, B. M., Jin, B., and Lant, P. (2003). Impacts of structural characteristics on activated sludge floc stability. Water Res. 37, 3632-3645. doi: 10.1016/S00431354(03)00291-4

Wilén, B. M., Liébana, R., Persson, F., Modin, O., and Hermansson, M. (2018). The mechanisms of granulation of activated sludge in wastewater treatment, its optimization, and impact on effluent quality. Appl. Microbiol. Biotechnol. 102, 5005-5020. doi: 10.1007/s00253-018-8990-9

Williams, H. D., and Davies, J. C. (2012). Basic science for the chest physician: Pseudomonas aeruginosa and the cystic fibrosis airway. Thorax 67, 465-467. doi: 10.1136/thoraxjnl-2011-201498

Woodhouse, J. N., Ziegler, J., Grossart, H. P., and Neilan, B. A. (2018), Cyanobacterial community composition and bacteria-bacteria interactions promote the stable occurrence of particle-associated bacteria. Front. Microbiol. 9:777. doi: 10.3389/fmicb.2018.00777

Worlitzsch, D., Tarran, R., Ulrich, M., Schwab, U., Cekici, A., Meyer, K. C., et al. (2002). Effects of reduced mucus oxygen concentration in airway Pseudomonas infections of cystic fibrosis patients. J. Clin. Invest. 109, $317-325$.

Wurl, O., and Holmes, M. (2008). The gelatinous nature of the sea-surface microlayer. Mar. Chem. 110, 89-97. doi: 10.1016/j.marchem.2008.02.009

Wurl, O., Miller, L., and Vagle, S. (2011). Production and fate of transparent exopolymer particles in the ocean. J. Geophys. Res. Ocean 116:C00H13. doi: 10.1029/2011JC007342

Xia, Z., Xiao-chun, W., Zhong-lin, C., Hao, X., and Qing-fang, Z. (2014). Microbial community structure and pharmaceuticals and personal care products removal in a membrane bioreactor seeded with aerobic granular sludge. Appl. Microbiol. Biotechnol. 99, 425-433. doi: 10.1007/s00253-014-5984-0

Yamaguchi, T. (2004). Human salivary aggregation in Streptococcus intermedius type g strains: relationship with IgA. FEMS Immunol. Med. Microbiol. 41, 101-107. doi: 10.1016/j.femsim.2004.01.008

Yang, Y., Song, W., Lin, H., Wang, W., Du, L., and Xing, W. (2018). Antibiotics and antibiotic resistance genes in global lakes: a review and meta-analysis. Environ. Int. 116, 60-73. doi: 10.1016/j.envint.2018.04.011
Yin, W., Wang, Y., Liu, L., and He, J. (2019). Biofilms: the microbial "protective clothing” in extreme environments. Int. J. Mol. Sci. 20:E3423. doi: 10.3390/ ijms20143423

Yuan, Q., Gong, H., Xi, H., Xu, H., Jin, Z., Ali, N., et al. (2019). Strategies to improve aerobic granular sludge stability and nitrogen removal based on feeding mode and substrate. J. Environ. Sci. (China) 84, 144-154. doi: 10.1016/j.jes.2019.04. 006

Zäncker, B., Bracher, A., Röttgers, R., and Engel, A. (2017). Variations of the organic matter composition in the sea surface microlayer: a comparison between open ocean, coastal, and upwelling sites off the Peruvian coast. Front. Microbiol. 8:2369. doi: 10.3389/fmicb.2017.02369

Zäncker, B., Engel, A., and Cunliffe, M. (2019). Bacterial communities associated with individual transparent exopolymer particles (TEP). J. Plankton Res. 41, 561-565. doi: 10.1093/plankt/fbz022

Zeng, G., Vad, B. S., Dueholm, M. S., Christiansen, G., Nilsson, M., Tolker-Nielsen, T., et al. (2015). Functional bacterial amyloid increases Pseudomonas biofilm hydrophobicity and stiffness. Front. Microbiol. 6:1099. doi: 10.3389/fmicb.2015. 01099

Zhang, T., Shao, M. F., and Ye, L. (2012). 454 Pyrosequencing reveals bacterial diversity of activated sludge from 14 sewage treatment plants. ISME J. 6, 1137-1147. doi: 10.1038/ismej.2011.188

Zhang, W., McLamore, E. S., Garland, N. T., Leon, J. V. C., and Banks, M. K. (2013). A simple method for quantifying biomass cell and polymer distribution in biofilms. J. Microbiol. Methods 94, 367-374. doi: 10.1016/j.mimet.2013.07.022

Zhao, X., Chen, Z. l, Wang, X. C., Shen, J. M., and Xu, H. (2014). PPCPs removal by aerobic granular sludge membrane bioreactor. Appl. Microbiol. Biotechnol. 98, 9843-9848. doi: 10.1007/s00253-014-5923-0

Zhou, J., Mopper, K., and Passow, U. (1998). The role of surface-active carbohydrates in the formation of transparent exopolymer particles by bubble adsorption of seawater. Limnol. Oceanogr. 43, 1860-1871. doi: 10.4319/lo.1998. 43.8.1860

Zhu, C. M., Zhang, J. Y., Guan, R., Hale, L., Chen, N., Li, M., et al. (2019). Alternate succession of aggregate-forming cyanobacterial genera correlated with their attached bacteria by co-pathways. Sci. Total Environ. 688, 867-879. doi: 10.1016/j.scitotenv.2019.06.150

Zhu, Y. G., Zhao, Y., Li, B., Huang, C. L., Zhang, S. Y., Yu, S., et al. (2017). Continental-scale pollution of estuaries with antibiotic resistance genes. Nat. Microbiol. 2:16270. doi: 10.1038/nmicrobiol.2016.270

Zita, A., and Hermansson, M. (1997). Effects of bacterial cell surface structures and hydrophobicity on attachment to activated sludge flocs. Appl. Environ. Microbiol. 63, 1168-1170.

Zobell, C. E. (1943). The effect of solid surfaces upon bacterial activity. J. Bacteriol. $46,39-56$.

Zobell, C. E., and Allen, E. C. (1933). Attachment of marine bacteria to submerged slides. Proc. Soc. Exp. Biol. Med. 30, 1409-1411. doi: 10.3181/00379727-306954

Zobell, C. E., and Allen, E. C. (1935). The significance of marine bacteria in the fouling of submerged surfaces. J. Bacteriol. 29, 239-251.

Zobell, C. E., and Anderson, D. Q. (1936). Observations on the multiplication of bacteria in different volumes of stored sea water and the influence of oxygen tension and solid surfaces. Biol. Bull. 71, 324-342. doi: 10.2307/1537438

Conflict of Interest: The author declares that the research was conducted in the absence of any commercial or financial relationships that could be construed as a potential conflict of interest.

Copyright (C) 2020 Cai. This is an open-access article distributed under the terms of the Creative Commons Attribution License (CC BY). The use, distribution or reproduction in other forums is permitted, provided the original author(s) and the copyright owner(s) are credited and that the original publication in this journal is cited, in accordance with accepted academic practice. No use, distribution or reproduction is permitted which does not comply with these terms. 